Article

\title{
Sustainable Consumption Using the Example of Food Processing in a Restaurant
}

\author{
Sergej Gričar ${ }^{1,2, *}$ and Violeta Šugar ${ }^{3}$
}

check for updates

Citation: Gričar, S.; Šugar, V. Sustainable Consumption Using the Example of Food Processing in a Restaurant. Sustainability 2021, 13, 13868. https://doi.org/10.3390/ su132413868

Academic Editor: Michael S. Carolan

Received: 6 November 2021

Accepted: 13 December 2021

Published: 15 December 2021

Publisher's Note: MDPI stays neutral with regard to jurisdictional claims in published maps and institutional affiliations.

Copyright: (c) 2021 by the authors. Licensee MDPI, Basel, Switzerland. This article is an open access article distributed under the terms and conditions of the Creative Commons Attribution (CC BY) license (https:/ / creativecommons.org/licenses/by/ $4.0 /)$.
1 Faculty of Economics and Informatics, University of Novo Mesto, 8000 Novo Mesto, Slovenia

2 Biotechnical Faculty, University of Ljubljana, 1111 Ljubljana, Slovenia

3 Faculty of Economics and Tourism “Dr Mijo Mirković”, Juraj Dobrila University of Pula, 52100 Pula, Croatia; vsugar@unipu.hr

* Correspondence: bojnec.gricar@gmail.com

\begin{abstract}
While strategy is of great importance in the hospitality industry, this article is in regard to the process. Therefore, for the first time, this article examines how stuffed yellow peppers are frozen (congelé) and later served as a portion of hot food in restaurants. A sensory analysis was performed, and tasters were invited. Data were collected over three different periods that represented the duration of freezing. The results of the descriptive statistical analysis indicated that the evaluated frozen dishes exhibited degrees of sensory deterioration. The findings are critical to the restaurant business because recipes are often skipped, and the process depends solely on the chefs. The primary value added for management is that strict recipes could improve the cost and shelf life of meals prepared and then frozen in the restaurant by lowering the storage temperature or shortening the freezing time. Incidentally, such analysis should be a continuous development to reduce energy consumption and increase food quality. The consistent results first demonstrated a decreased mouthfeel of the sauce after the first month and, second, a higher stickiness after two months of freezing. In addition, the nutritional values of the dish were calculated using trademarked software.
\end{abstract}

Keywords: efficiency management; frozen food; restaurant business; sensory analysis; stuffed pepper; quality

\section{Introduction}

The main theoretical contribution of this work is to promote the sustainable development of restaurant business processes through several factors that determine the modern business strategy: optimizing costs as restaurant operational challenges, increasing the quality of prepared food, meeting consumer demands combined with green thinking of frozen food and its organoleptic properties, and finally, reducing energy loss in terms of sustainable consumption vs. production as determined by sensory analysis. Therefore, the first specific objective (SO1) was to provide a comprehensive analysis of previous research that has contributed to sustainable consumption concerning the processing industry.

This study aims to demonstrate the importance of recipes for the restaurant business using frozen stuffed peppers as an example and accurately measure the dish's quality following the freezing and thawing stages. The motivation for this study arises from cases where restaurant managers, owners, or chefs rarely contributed to the standardised factors that could influence the quality of the food, especially that of the served dish, most likely in ready-to-eat frozen products [1]. It is crucial to consider the customers willing to eat the food in restaurants or eat out (take-out or takeaway). Alternatively, the restaurant should optimise its processes due to sustainable thinking or a lack of energy or staff. At the same time, one of the optimisation processes is to prepare the food in advance to serve the highest demand of the day.

Therefore, the second specific objective (SO2) was how the particular food was prepared and what the impact of this food on the freezer units waas. The purpose of SO2 
was to measure the temperature and duration of storage, while that of the third specific objective (SO3) was to test the quality of the specific foods through sensory analysis with the recruited tasters. Overall, the experiment was conducted with restaurant-produced frozen (congelé) and post-production stuffed sweet yellow peppers (vegetables, e.g. Palana Babur or Peppers Babur) (the pepper).

However, the next section clearly defines the purpose of this article and places the research findings presented in the third section in the context of implementing the postulates of sustainable consumption. The importance of the analysed technological issues as a tool for the implementation of the principles of sustainable consumption versus production is shown. The development of the food industry (e.g., the restaurant business) is discussed in this research.

This article is organised as follows. The method and data are presented following the literature review. The fourth section presents the main results, followed by a discussion section. The last section concludes the article and highlights the limitations and possible future research opportunities.

\section{Literature Review}

The post-pandemic world, the new normal in many service industries, is searching for better future service initiatives to serve guests, including online, fast, fashionable, high-end, and social (humane) networking. The observation method suggests that the generations using the internet during lockdown felt too connected online and consequently missed real social (humane) connections. Therefore, the catering industry needs to take a new path towards developing its service structure, and the service should be at a high level even with low overall prices (e.g., low-cost or self-service restaurants).

Some industries are moving further towards robotisation, whilst others maintain a service method that is more human-orientated, such as with lodging or food and drink service. Hence, the food quality depends more on the subjective decisions of the restaurant staff than on objective protocols. Eateries have thus far suffered significantly due to the pandemic, and therefore, the quality of the food and service should be focused upon in addition to ways to help the industry recover. This article provides comprehensive research regarding the quality of frozen food, specifically meals, starting with the preparation, followed by cooking to freezing, and finally reheating and serving.

\subsection{Restaurant Operational Challenges}

The researched industry is an emerging business that addresses quality issues based on food safety principles. The food aspect in the restaurant usually deals with the influences of primary production and food processing only. Therefore, this study provides insight into food recipes and validation. However, this attribute is mainly presented due to this ground-breaking study's sensory analysis methodology of frozen stuffed "sweet yellow peppers (vegetables), such as Palana Babur or Peppers Babur" (Appendix A), hereafter named as peppers.

Alternatively, guests are only willing to pay for high-quality services that offer value for their money [2]. A recent study on frozen stuffed peppers demonstrated no previous scientific contributions [3] to this trendy and healthy Mediterranean dish, as the authors discussed [4]. On the other hand, chefs make mistakes in dealing with vulnerable aliments such as minced meat that could result in severe diseases [5-7]. Overall, this study contributes to food science on multiple levels, namely (1) by highlighting the importance of recipes in gastronomy, (2) presenting the most straightforward standard, that being food preservation, (3) a literature review and validation of the impact of the freezing process on the quality of a dish, and (4) discussing the results of sensory analysis of a feature dish as an example.

In most cases, freezing is a very effective method of preserving the quality of the nutritional properties. However, freezing and storing almost always results in physical and chemical changes that incur a loss of quality. The extent of the damage depends 
on several factors, including the freezing and storage technique used, the application of treatments before freezing, and the type of food. The application of appropriate prefreezing treatments, recipes, and adherence to storage conditions often minimises spoilage. For example, specific problems associated with frozen foods, such as gelation of egg yolks, enzymatic browning of fruit tissues, and rancidity of vegetable (corn) and animal tissues, can be minimised by the application of treatments before freezing. Frozen foods can lead to quality problems which are especially perceived in vegetables. Additionally, enzymatic browning is determined by oxidation of the oxidoreductases present in vegetables. Their inactivation takes place by blanching. Freezing damage can limit the product's shelf life when frozen, such as through the rapid onset of oxidative rancidity in meat or the loss of texture during the frozen storage of peppers and ready-to-eat meals [8-10].

In some cases, the damage from freezing is so significant that the product is no longer acceptable. The loss of turgor pressure in raw vegetables such as tomatoes and lettuce could result in a flabby product. Such a product does not meet consumer expectations for salad components [8].

Several authors have studied frozen dishes and reported the consequences of freezing [11-16]. On the other hand, a few researchers have included dining operations where chefs prepare dishes in technological and thermal ways [17] that can be frozen for later use. These phenomena $[17,18]$ where standards have been neglected and declined in the business $[19,20]$ are examined in our study. In this regard, evenness is one of the most critical phases that could increase productivity in restaurants [21,22] and boost wages [23,24]. The hospitality industry suffered from staff shortages during the economic expansion [25] and the pandemic and probably afterwards in most European countries. The reported staff shortages are likely in the United Kingdom of Great Britain and Northern Ireland (UK), where the pandemic and Brexit are threatening to create a deep crisis in the Hotel/Restaurant/Café (HoReCa) industry. One of the possible means for better planning and quality measures is uniformity, where pre-made dishes for peak times could prevent several problems, including staffing issues and quality measurement. Therefore, the study of frozen food in restaurants is a hot topic, while freezing is recognised as one of the best methods of preserving food quality [26].

Some previous research [27] mentioned and studied the frozen pepper in different technical aggregates (e.g., cut, pureed, or as a powder) considering quality measurement. The cut red pepper was frozen and lost some vitamins and colour quality when reheated, as reported in $[26,27]$. Few researchers have reported on sweet peppers, and only one reported on yellow peppers (vegetables) [28]. Therefore, this is the first study on (1) frozen sweet yellow peppers (vegetables) and (2) stuffed sweet yellow peppers (vegetables) using sensory analysis.

\subsection{Prepared Food}

Prepared meals, consisting of various ingredients impacting the shelf life, represent a very complex topic. Amongst the essential issues regarding ready meals, the possibility of microbiological contamination during the technological preparation phase, storage, and insufficient thermal regeneration are included. For example, prepared foods (i.e., meals), have undergone all the necessary technological processes during the manufacturing process, including preservation. They have a specific shelf life and are ready for immediate consumption or regeneration before eating [28].

According to Leistner et al. [29], the shelf life of most foods is a result of the combined effects of many demanding parameters. Each of them is an inhibiting factor for the development of the microbial association and native enzymatic backgrounds but insufficient for visible effects. Therefore, as many barriers as possible are needed if the product is to be microbiologically stable for the so-called "barrier technology".

It is crucial to determine the conditions and requirements for the shelf life and to meet them precisely. There are essential differences between the stability under ideal conditions (laboratory) and typical storage in restaurants. Concerning the latter, it is challenging 
to define shelf life limits because freezer temperatures during a restaurant's operational business processes can change frequently. According to Stražiščar et al. [30], the Hazzard Analysis Critical Control Point system allows such deviations in storage temperature for a short time. Therefore, a link between specific microbiological requirements and the simultaneous monitoring of sensory properties (e.g., appearance, taste, smell, and texture) is necessary to determine the shelf life [31]. It is most effective to monitor both parameters (temperature and shelf life) for ready-to-eat and frozen food produced solely in the restaurant at specific time intervals to better determine the tenacity over time. Protocols must be established for these processes to ensure safety and quality. However, the practice in the restaurant business is complicated by several factors, such as peak hours and the difficulty of maintaining a constant temperature in the freezer. Therefore, this study is important for gaining accurate insight into possible consumption improvements in restaurant business processes.

The production of ready meals includes the following phases: (1) pre-preparation of raw materials, (2) preparation (heat treatment process), (3) packaging, (4) preservation, (5) storage, and (6) regeneration or heating. Restaurant pre- and preparation processes are, in principle, the same for all categories of ready meals. The following technological processes, such as packaging, preservation, and storage, are specific to each dish. Depending on the distribution, preservation, and storage type, ready meals are divided into hot, chilled, pasteurised, sterilised, frozen, and dehydrated [28].

\subsection{Frozen Food and Sensory Treatment}

Frozen ready meals can be defined in technical terms as prepared culinary products stabilised in a new state by the freezing process ( $\mathrm{T}$ is lower than $-40{ }^{\circ} \mathrm{C}$ ) and stored at a temperature lower than $-18{ }^{\circ} \mathrm{C}$ after maximum crystallisation is reached. In this temperature range, the growth of microorganisms is stopped, and quality changes are due to the actions of enzymes. Today, the restaurant business offers a diverse range of frozen ready meals, as with few exceptions, practically everything is prepared in regular culinary practice. A wide range of multi-component dishes is made possible by the process of preservation by freezing (below $-18^{\circ} \mathrm{C}$ ), which practically does not change the sensory or nutritional quality of the food. Freezing is an effective means for the preservation of the colour and flavour of the dish. However, great care must be taken when preparing combined dishes (e.g., sauce, meat, vegetables, and starchy foods) if the raw materials are prepared differently (e.g., fresh or heat-treated).

Frozen ready meals must also be hygienic. The effects of freezing on microorganisms depend on the following: the type and number of microorganisms, the degree and speed of freezing, the nutrient composition, the $\mathrm{pH}$ level, the presence of cryophilic agents, the temperature and storage time, and the speed and method of thawing.

The most significant reduction in the microbial population occurs during freezing itself or immediately after freezing. Gram-positive bacteria are more resistant to freezing and thawing than Gram-negative bacteria, and bacterial spores are the most resistant. The cells show the most significant resistance at the stationary phase, while young cells are most susceptible to freezing and thawing. Microorganisms grow more intensively at temperatures above $-8{ }^{\circ} \mathrm{C}$. Many pathogenic microorganisms are significantly reduced during storage, but this should never substitute good hygiene during production [30]. Some enzymes of microorganisms are active even at lower temperatures. Thawing with microwaves has the most destructive effect on microorganisms. Microwaves induce rapid and robust vibrations of nuclear matter and thus decompose it [32].

Freezing may prolong the shelf life but can lead to undesirable deterioration of the sensory properties. The changes are apparently due to the formation of ice crystals during the freezing process. The change in flavour is mainly due to hydrolytic and oxidative changes in the fats and the action of peroxidases in vegetables, which are not entirely inactivated by freezing. In addition to the stability of the individual ingredients, several 
additional factors must be considered in the compositions of prepared foods. These factors could result in an association between the flavour and the ingredients.

In particular, the problem with compound dishes is the change in taste and smell due to the volatility and transition of the aromatic components. These findings are illustrated in Table 1 [32]. Onions and garlic are good examples of enzymatic reactions that cause a loss of characteristic flavour and odour. A frozen meat dish lacks harmony between its spices. Most spices lose intensity, while the aroma of pepper, for example, does not change.

Table 1. Changes in odours and tastes when storing frozen dishes.

\begin{tabular}{|c|c|c|}
\hline Food & Foreign Smells and Tastes & Causes \\
\hline potato slices & rancid, oily, after legumes, after colour & auto-oxidation \\
\hline cauliflower, Brussels sprouts, beans & by colour, sulphur, by cabbage & $\begin{array}{l}\text { enzymatic reactions, oxidation and } \\
\text { degradation of amino acids }\end{array}$ \\
\hline peas & sour & enzymatic reactions, lipid oxidation \\
\hline green beans & on the grass, on the hay & enzymatic reactions, lipid oxidation \\
\hline meat & $\begin{array}{c}\text { bitter, rancid, after fruit, oily, after milk, } \\
\text { after grass }\end{array}$ & microbial oxidation of lipids \\
\hline
\end{tabular}

Packaging is a process that plays a crucial role in extending shelf life, especially as a parameter of barrier technology. Vacuum packaging, active packaging, or packaging in modified atmosphere packaging (MAP) are optimal today [33,34]. When packaging cold foods and meals, it is essential to know that Clostridium botulinum's bacterium grows even without oxygen.

Foods are packaged before or after freezing, but it is essential to remember that packaged foods freeze more slowly because of the insulating effect of the packaging. The packaging must be as close as possible to the product's surface to prevent freezing and prevent access to oxygen and light. Packaging materials must be mechanically resistant to low temperatures and the thermal regeneration temperatures of the ingredients (up to $100{ }^{\circ} \mathrm{C}$ when heated in boiling water, from $150{ }^{\circ} \mathrm{C}$ to $160^{\circ} \mathrm{C}$ when heated in convection and microwave ovens, and $225^{\circ} \mathrm{C}$ when heated on a plate).

Various packaging materials are used for the packaging of frozen ready meals. Due to its resistance to high temperatures (up to $124^{\circ} \mathrm{C}$ ), polyethene is very suitable for ready meals that need to be heat treated and regenerated directly in the packaging before use. Polyethene is impermeable to liquids and only slightly permeable to water vapour. It is suitable for packaging frozen foods due to its exceptional flexibility at low temperatures [35]. Trays coated with aluminium or polypropylene are also used. Polypropylene is impermeable to grease and has low permeability to steam and gasses. It can withstand temperatures from $-10^{\circ} \mathrm{C}$ to $150^{\circ} \mathrm{C}$. A biaxial orientation improves resistance at lower temperatures, withstanding temperatures as low as $-60^{\circ} \mathrm{C}$, and it is also used in freezing [36,37].

The combination of polyamide and polyethene (PA/PE) results in an oxygen- and water vapour-impermeable film. Polyester/polyethene film has excellent mechanical properties. If polyvinylidene chloride is added, the properties of the film are further improved, and an excellent film for packaging frozen meals is obtained, whereas the newest product (PA/PE re-granulated product) is foreseen for the circular economy [38].

During storage and distribution, ready meals require packaging to maintain their quality and protect against damage. It also provides a barrier against microorganisms, insects, moisture, gasses, and foreign flavours. Cardboard packaging is commonly used to protect the primary packaging from the physical and mechanical effects of the environment [39].

The storage temperature mainly influences the shelf life of frozen meals [40]. Temperature fluctuations are not allowed; otherwise, ice crystals will form and affect the product's texture. The duration of freezing at $-18{ }^{\circ} \mathrm{C}$ is from a few months to a year, but frozen ready meals can be stored at $-30{ }^{\circ} \mathrm{C}$ for about 6 months without the risk of noticeable sensory changes. In determining the shelf life of a frozen meal, the practical storage time (PST), the barely perceptible quality difference (QD), and the high-quality period (HQP) are 
determined. The PST determines the time when the product still has the expected quality. The QD is the storage time when at least $70 \%$ of trained inspectors can distinguish stored products from fresh samples. The PST is mainly determined by sensory evaluation of the product stored from $-30^{\circ} \mathrm{C}$ to $-40{ }^{\circ} \mathrm{C} 2-5$ times. For foods that are very sensitive to colour loss (e.g., peaches, cauliflower, and redfish meat), the PST is very close to the QD. It is also necessary to determine the PST at the actual commercial temperatures (usually at $-18^{\circ} \mathrm{C}$ ) and not only at the desired storage temperatures (from $-30{ }^{\circ} \mathrm{C}$ to $-40{ }^{\circ} \mathrm{C}$ ) [41].

Prepared foods represent a very complex area in terms of shelf life, as they are made up of various components that individually affect the shelf life. It is necessary to identify the ingredient most susceptible to loss of flavour, discolouration, and rancidity. When determining stability, it is necessary to indicate the storage time at specific temperatures marked in the trade $\left({ }^{*}-6{ }^{\circ} \mathrm{C},{ }^{* *}-12{ }^{\circ} \mathrm{C}\right.$, and $\left.{ }^{* * *}-18^{\circ} \mathrm{C}\right)$. The quality of frozen food depends on the storage temperature, time, composition, and quality of raw materials and technologies (i.e., production and freezing of the packaging) [42].

The best final quality is obtained in compound meals when the individual ingredients are separately prepared. In a meal consisting of noodles, meat, and vegetables, the noodles are packed raw, and the vegetables are only blanched, while the meat can be fully processed. During storage, the main changes that affect the quality are loss of weight (water), loss of volatile components, oxidative changes in lipids, denaturation of proteins, change in colour, and the transfer of aromatic constituents from product to product. Volatile aromatic compounds originate from the surface of the product. They can pass through the air to other products, where they cause strange odours and flavours by being deposited in the aqueous or fatty phase. For the original product, however, this means a loss of characteristic taste and odour [43].

Physical changes in food depend on changes in the physical state of its water. Complimentary water, which is a free liquid in food, freezes depending on the solute content [44]. The more the free water freezes, the better the quality of the frozen food. Despite the high free water content in most foods, the freezing point decreases due to the dissolved substances from natural and colloidal solutions. When the food is cooled to the freezing point, the water turns to ice while heat continues to be released. When we freeze food, we lower the temperature below the cryoscopic point of its juices. Most water crystallises in a temperature range that is $2-3^{\circ} \mathrm{C}$ below the freezing point. This process is the so-called ice crystal formation range or critical zone (usually between $0{ }^{\circ} \mathrm{C}$ and $-5^{\circ} \mathrm{C}$, depending on the composition of the food). The point at which the temperature transitions into this range is critical to the quality of the frozen food. First, when the surface is frozen, the food crystallises in depth. Consequently, the liquid in the centre is concentrated and frozen at a temperature between $-60{ }^{\circ} \mathrm{C}$ and $-65{ }^{\circ} \mathrm{C}$. Freezing to this point is expensive, so temperatures around $-20^{\circ} \mathrm{C}$ are usually used [45].

When freezing food, the effect on the quality as determined by the characteristics of the food is to be checked. Most experts advocate for fast freezing because the ice crystals are much smaller and spread intracellularly. The water is inside the cells and does not have time to enter the intracellular spaces. During slow freezing, large crystals form intercellularly because the water diffuses the cells into the intercellular spaces and settles on the crystals already there, making them more prominent. Smaller crystals do minor damage to the cell structure [46].

The higher the water content of the food, the better its ability to freeze produce a higher percentage of ice. To keep the loss of frozen food as low as possible, a low and constant temperature in the storage room and high relative humidity are required. Recrystallisation processes (damage to the colloidal composition of the cell) play an essential role in the structural changes of food. The consequence of these irreversible processes during food thawing is a greater or lesser loss of juice, which alters the quality of the frozen product [39]. At low temperatures, enzyme activity is reduced but not completely stopped. It affects changes in the odour, taste, and colour (lipases: hydrolysis of fats; pectinase: the destruction of the cell wall of plants; and polyphenol oxidase: catalyses rust reactions). Ice crystals 
also play an important role in enzymatic changes by disrupting membranes and allowing enzymes to access cells.

The growth of microorganisms in frozen foods is inhibited by temperature and water activity. Since the freezing point of solid food is lower than the freezing point of water, they turn into ice. This change causes an increase in the solute concentration and a decrease in water activity, interrupting the metabolic processes of microorganisms. Gram-positive bacteria are more resistant to freezing than Gram-negative bacteria, and bacterial spores are most resistant to freezing damage [47].

Freezing slows the chemical reactions in foods, but protein denaturation, starch breakdown, and fat oxidation can still occur. Slow freezing alters the colloidal structure of proteins and reduces their ability to bind water. The extent of denaturation depends on the length of time frozen foods are stored. The extent of denaturation depends on how long the frozen food is stored. Oxidative spoilage occurs in frozen foods that contain high levels of fat. Boltman [48] stated that the development of radiation in frozen foods is significantly reduced at $-34^{\circ} \mathrm{C}$. Low temperatures, especially freezing temperatures, also affect the quality of starches and starch products. The consequences are the loss of a smooth, tender texture and loss of water during thawing. The starch granules, which consist of amylose and amylopectin, swell at a temperature of $50-60{ }^{\circ} \mathrm{C}$ and then change into a soluble form (starch gluten). When the starch is cooled, a thick starch paste forms a gel that releases water (this is avoided if the products are heated to $140-150{ }^{\circ} \mathrm{C}$ ). Common household starches (e.g., wheat and corn) contain only $16-25 \%$ amylopectin and lead to a high retrogradation rate, which means that these starches are not suitable for freezing. If recrystallisation processes occur during freezing at low temperatures and shorter storage times, the quality of the frozen starch product is not significantly affected [49]. On the other hand, household starches are commonly used in restaurants. Therefore, this assessment is an opportunity to exchange information between practitioners and scientists.

\subsection{Sustainable Consumption vs. Production}

Sustainable consumption is a process consisting of striving to achieve long-term, sustainable socioeconomic goals, taking into account extremely important environmental aspects [50]. The findings of Wang et al. [50] strongly suggest that European countries are international leaders in sustainable consumption and production practices. These studies motivated the identification of opportunities in the sensory analysis of stuffed pepper.

The current use of human resources is not in line with the goal of sustainable development. Agriculture and food production have a particularly high share of the impact, and this is also true for food consumption. Transforming food production plays a critical role in addressing the challenges, and sensory consumer science can contribute.

Restaurant businesses seeking sustainable transformation are turning to consumer sensory science in droves to achieve sustainability. Based on a comparison of previous research [51], a categorisation of six contributions that consumer sensory science can make to sustainable development is proposed, which includes (1) promoting a dietary shift towards more sustainable foods and diets, (2) increasing food diversity, (3) reducing food waste, (4) improving the circular economy of the food system, (5) increasing and prioritizing food-related well-being, and (6) addressing the impact of climate change on $\mathrm{CO} 2$ emissions and energy consumption during the freezing period. On the other hand, some other authors propose a differentiated performance of six factors [52,53]. According to their modelling analysis, the six factors can promote the following sustainable consumption practices: (1) the cultivation of sustainable consumption awareness, (2) the government's role in modelling, (3) a set of laws, regulations, and policies, (4) a thorough action plan for sustainable consumption, (5) the insistence of businesses and consumers on sustainable production and consumption, and (6) the concerted efforts of various stakeholders. Moreover, standardisation leads to a differentiation of lifestyles not only in the restaurant business but also among individuals, such as well-being, consistent 
minimalism in consumption [54], and online shopping [55]. Nevertheless, government interventions [56] could help to achieve "green" outcomes [57].

Sensory studies in consumer science have focused on foods that are considered sustainable (e.g., organic, sustainably grown, and meat alternatives) and aspects that contribute to sustainability (e.g., shelf life, consumption of fruits and vegetables, and unfamiliar foods). The idea for this research is to design a sensory analysis of ready-to-eat foods that target six necessary changes that can increase the contribution of the studied disciplines to sustainable consumption $[51,54]$ and communication between companies, consumers, and theory [58-60].

\section{Materials and Methods}

Food quality is defined as a combination of characteristics that have a decisive influence on how the consumer accepts food (Bolek) [61]. These characteristics are nutritional value, microbiological integrity, toxic substances, heavy metals, pesticides, shelf life, suitability, price, and sensory characteristics (appearance, smell, taste, colour, and texture). The sensory properties can be perceived and evaluated by anyone who buys, prepares, and consumes food or beverages.

Sensory analysis is the oldest method of verifying food quality. When we knowingly or unknowingly select or consume foods, we evaluate them intentionally or unintentionally and decide for or against them based on our impressions. Sensory analysis is the description and evaluation of the properties of food using the human senses. Therefore, they are a measurement tool to determine the quality or condition of food. They include sensory evaluation procedures, standardisation of terms and methods, as well as statistical processing. Sensory evaluation is subject to many influences, including personal choice, prejudice, health status, social, cultural, and religious factors, climatic conditions, general physical condition, education, or cultural influence [62,63].

Humans have five senses to perceive and evaluate sensory characteristics: taste, smell, sight, hearing, and touch. The process of sensory perception takes place in such a way that peripheral receptors react to an external stimulus with an electrical impulse, which is transmitted via nerve fibres to the central nervous system and the corresponding brain centre. Then. it is registered (reception), recognised (perception), and evaluated. What follows is a reflection and decision about the stimulus. The integration of the individual sensory information can take place in the central nervous system. Sensory receptors are detectors of physical and chemical changes in the environment and organism. They are specialised receptor cells or particular receptor sites that respond to only one type of stimulus (e.g., a taste stimulus does not stimulate the visual receptor). However, they can respond to other stimuli under certain conditions, but the response is somewhat worse [64].

\subsection{Developing a Hypothesis}

Preservation of vegetables and fruits by freezing is one of the essential methods of maintaining the quality of food and dishes in the restaurant business, which can be kept for more than $48 \mathrm{~h}$ after refrigeration. Such products are suitable for human consumption and are nutritious as long as high-quality raw materials are used, good restaurant standards are maintained, and the products are shelf-stable.

Stuffed peppers are a typical dish in many cuisines. They consist of hollowed-out peppers stuffed with various fillings, often meat, vegetables, rice, or sauce. The dish is usually prepared by filling the cavities of the peppers and then cooking them. The Balkan variety consists of peppers (Appendix A) stuffed with minced meat and rice. The name means a variant of "stuffed peppers" in all languages. It is most popular in the eastern regions and is influenced by Hungarian cuisine. The meat, usually ground beef and pork, is mixed with herbs, onions, spices, and rice and then cooked in a sauce of oil, tomatoes, and spices.

Based on the previous sections and literature review, the hypothesis is that a long freezing period will significantly decrease the quality of the stuffed pepper and will also 
depend on the storage temperature. The hypothesis was derived using descriptive statistics, where data were obtained through a sensory analysis, for which tasters were recruited.

\subsection{Sensory Analysis}

Sensory analysis as a method of obtaining data for research is presented. The most appropriate sensory evaluation method was selected according to the purpose of the evaluation or the expected results. Sensory methods are divided into two broad groups: (1) analytical laboratory tests used for examining products for differences to determine sensory characteristics and (2) practical consumer tests or acceptance tests used to evaluate products quality and popularity or acceptability from the consumer's point of view and to determine which sensory characteristics motivate consumers to choose certain foods over others. Sensitivity tests are used to measure a person's ability to perceive and recognise sensory characteristics (e.g., determination of perception threshold, recognition, and differentiation for tastes, smells, colours, and sense of touch). Analytical tests are further divided into sub-sampling (i.e., differentiation analytical tests) and furthermore to quantitative and qualitative tests.

Differentiation analytical tests are used when minor differences are expected in the determination of sensory characteristics. First, the pairwise comparison is based on a simple choice between two options and provides information on whether there is a perceptible difference between samples $x$ and $y$ in a particular sensory property (e.g., colour or sweetness) and which sample it is. The second is the triangle test. In this test, we looked for the difference between two samples: $x$ and $y$. Three coded samples were presented to the taster at the same time. Two of them were the same, and one was different. The tester had to determine which sample was different. The third, the duo-trio test, was a combination of the first two and looked for whether there was a difference between the samples assessed. The taster was presented with three samples: two were the same (i.e., coded), and the third was different (marked with a K).

Quantitative analytical tests were used to evaluate the differences present between the samples. These tests could be performed in two ways: ranking and scoring. The ranking was an extended pairwise comparison. This method was suitable for the quick classification of samples according to a single property or criterion. The taster should have received a maximum of five samples at a time. The ranking answered the question of which of the samples had the strongest or least pronounced particular property. The advantage of ranking is that the same sample can be classified according to different properties. The results of the two rankings can be compared if the samples are the same. The ranking is one of the most critical tasks in the routine evaluation of sensory properties. The rating determines the intensity of a particular property of food. Grading is a complex physiological process in which tasters assess the expression of a food's positive or negative predetermined characteristics. Well-trained tasters are crucial. They should be familiar with the characteristics they are evaluating and the significance of different levels of expression. To reduce the variability of the rating group, the standards that anchor the tendency of a scale to slip over time were used. Several scales are available for expressing ratings, such as structured or unstructured (descriptive, point by point) scales, but they may not include a personal response. The number of observations depends on the samples and the tasters.

Qualitative analytical tests are descriptive analyses or profiling. Using descriptive analytical methods, the tasters determine and evaluate the essential characteristics of the food. This type of sensory analysis requires very well-trained tasters with an excellent ability to perceive, identify, and express food stimuli or sensory properties.

The tasters must meet several requirements. They should not have any food preferences. They should express their perceptions appropriately and have a sense of responsibility and reliability, the ability to concentrate, sensory memory, perseverance, a willingness and interest in working in a group, and adequate responsiveness. Shyness and criticism are not desirable features. The health condition of the taster has a significant impact on the globally regulated analysis. For example, the condition of the teeth affects the response to 
sour, astringent, or metallic aftertastes in fillings. The effect of medications influences taste. A high threshold for sodium chloride (salt) occurs in hypertension. Heart patients have a greater chance of perceiving a bitter taste. All this is also influenced by fitness and fatigue.

\subsubsection{Analysis Setting}

An analytical sensory test was used for sensory evaluation. Analytical tests are used primarily for laboratory evaluation of products and are used to determine the differences and similarities between products. Analytical descriptive tests are used to evaluate the expression of individual specific properties of the sample. The corresponding number of points precisely defines the importance of each property.

A committee of three members conducted sensory analysis of stuffed peppers samples after the pre-test $[65,66]$. As experienced tasters, these members exercised their collective expertise in sensory analysis and gastronomy. Their main skills and contributions included the following:

(1) A university member who has worked in the field of sensory analysis for 30 years and has issued hundreds of official protocols and decisions on food quality;

(2) Owner of a restaurant with more than 35 years of academic and professional experience in gastronomy and food protocols, including sensory analysis;

(3) The author of the project and research with several years of academic and practice organoleptic testing and sensory analysis in the food industry (retail and restaurant).

This collective skill set formulated taster credibility in analysing the targeted study goal (i.e., sensory analysis for the micro-, small-, and medium-sized restaurant business) and the third specific objective.

The food in the restaurant was prepared in the owner's kitchen. All three tasters took part in the sensory analysis at the same time and in the same place (e.g., in the dining room of the restaurant). Moreover, the tasters were exposed to the same light, humidity, and temperature.

The evaluation was carried out in three phases based on the pre-test and the definitions of the characteristics. Sensory evaluation was performed by classifying the properties. The test was analytical and descriptive with an unstructured point scale (1-7 points). The sensory characteristics of the samples were defined as the appearance of the sauce and peppers. The texture profile of the filling and sauce and the sauce's odour and flavour profiles were tested.

\subsubsection{Evaluation Criteria}

The criteria for the evaluation of the individual properties were as follows (point scale from 1 to 7 points):

I. Peppers (whole impression of the dish):

1. Smell (1-7 points: 1 = very poorly pronounced; $7=$ very well pronounced, typical smell);

2. Foreign odours (1-7 points: $1=$ foreign odours are not present; $7=$ sample with strongly pronounced foreign odours);

3. The dish's appearance (1-7 points: $1=$ changed, atypical shape, damaged peppers, unstable sauce; 7 = shape typical of stuffed peppers, no deformations of the peppers' shape, sufficient stability of the sauce);

4. Colour (1-7 points: $1=$ untypical, pale colour; $7=$ colour characteristic of stuffed peppers).

II. Sauce:

5. Sauce colour (1-7 points: 1 = uncharacteristic colour (pale, brownish, uneven; $7=$ the characteristic red colour of the sauce).

6. Sauce stability, assessing the characteristic visually. Place the sample on a plate and assess whether there is a separation of the components, particularly 
the water, fat, and starch phases (1-7 points: $1=$ unstable sample (strong separation of fat, water); 7 = unstable sample (no phase separation));

7. A gloss of sauce, with evaluation of the composition of the sauce ingredients (1-7 points: 1 = sauce without gloss, dried, cloudy; 7 = clean, smooth sauce, with gloss on the surface);

8. The aroma of the sauce (1-7 points: $1=$ faint and undesirable aroma; $7=$ perfectly pronounced, intensely characteristic aroma of the sauce);

9. The mouth sweetness feeling (1-7 points: $1=$ sample with inappropriate texture (rough, sticky, oily); 7 = a soft sensation in the mouth, no stickiness);

10. Homogeneity (1-7 points: $1=$ inconsistency between ingredients, lumps; 7 = perfectly homogeneous sample, bound components);

11. Thickness (1-4-7 points: $1=$ fluid pepper sauce; $4=$ adequate density; $7=$ too thick sauce).

III. Stuffing of the pepper:

12. Cross-sectional colour (1-7 points: $1=$ darkened grey colour of the stuffing; 7 = lovely pink colour of the stuffing mixture);

13. Cross-sectional composition (1-7 points: $1=$ meat and rice are out of proportion (more rice or meat); 7 = meat and rice are evenly distributed);

14. Lightness or compression ( $1-7$ points: $1=$ whipped filling; $7=$ light filling);

15. Sticky stuffing ( $1-7$ points: $1=$ no stickiness, easy to swallow; $7=$ filling sticky);

16. Fat (1-7 points: $1=$ no perception of fat; $7=$ the feeling of fat is strongly perceived);

17. Pepper flavour (1-7 points: $1=$ faint and undesirable aroma; $7=$ perfectly pronounced pepper aroma);

18. Pepper taste (1-7 points: 1 = pepper with strongly pronounced foreign aromas; 7 = pepper without foreign aromas).

IV. Lastly, the entire dish:

19. Taste (1-7 points: $1=$ sample with a strong foreign taste (sour, rancid, bitter); 7 = sample without a foreign taste (sauce and stuffed peppers);

20. Feel in the mouth (1-7: $1=$ inhomogeneous, sticky, untypical feeling; $7=$ without stickiness, fat content, characteristic of stuffed peppers);

21. Salt $(1-4-7$ points: $1=$ too little salty food; $4=$ suitable salt content; 7 = too salty);

22. Aroma harmony: when tasting in the mouth, we evaluated the consistency of the flavours of all ingredients and the intensity of flavours of added spices (1-7: $1=$ aroma harmony, too weak or too strong seasoning; 7 = aroma harmony and optimal seasoning).

V. Finale

23. Overall impression: the last sensory characteristic was evaluated, namely the overall acceptability of the product based on the previous sensory evaluation. This was not an average of the preliminary results (1-7: $1=$ inferior quality and total unacceptability; 7 = excellent overall sensory impression of quality).

\subsection{Descriptive Statistics}

Descriptive statistics were used to calculate the data obtained using sensory analysis. The sensory analyses were statistically processed using the GLM procedure in the SAS/STAT software package. The arithmetic mean $(\mu)$ was calculated by dividing the sum of all the values by the number of values. The following Equation (1) applies to this:

$$
\mu=\sum_{i=1}^{n} X_{i} / n,
$$

where the symbols denote $\mu$ notation for the arithmetic mean, $\sum$ represents the summation and sum, and $X_{i}$ is the symbol for each value of the variable $n$ index from 1 to $n$. 
Systematic influences were analysed for the stuffed pepper composition, freezing time, freezing temperature, batch, and evaluators. The following statistical parameters were used to represent the results obtained: $\mu$ is the arithmetic means, SD is the standard deviation, and CV (\%) is the coefficient of variability. Equation (2) was used to study the effect of the freezing time $\left(Z_{i} ; 1=\right.$ starting analysis, $2=$ after 1 month, and $3=$ after 2 months), freezing temperature $\left(\mathrm{T}_{\mathrm{j}} ; 1=\right.$ fresh (no freezing), $2=$ at $-18{ }^{\circ} \mathrm{C}$, and $3=$ at $-25^{\circ} \mathrm{C}$ ), and batches $\left(\mathrm{S}_{\mathrm{k}}\right.$, three batches). Furthermore, there was the taster $\left(\mathrm{O}_{1}\right.$, three tasters) for the sensory characteristics of the stuffed peppers. The interaction effect of $Z_{i j}$ was also included in the model (m):

$$
\mathrm{y}_{\mathrm{ijklm}}=\mu+\mathrm{Z}_{\mathrm{i}}+\mathrm{T}_{\mathrm{j}}+\mathrm{S}_{\mathrm{k}}+\mathrm{O}_{\mathrm{l}}+\mathrm{ZT}_{\mathrm{ij}}+\mathrm{e}_{\mathrm{ijklm}}
$$

where e is a standard error, where $y_{i j k l m}$ define dependent variable of all independent variables $X_{\mathrm{ij}}$ and $\mathrm{e}_{\mathrm{ijklm}}$ is standard error of the analysis.

Analysis of variance is used in experiments with multiple treated groups to determine whether there are statistically significant differences between the means, and it is performed according to the following procedure. The correlation coefficient (c) is defined in Equation (3):

$$
\mathrm{c}=\left(\sum_{\mathrm{j}=1}^{\mathrm{k}} \sum_{\mathrm{i}=1}^{\mathrm{n}} \mathrm{X}_{\mathrm{ij}}\right)^{2} / \mathrm{n} \cdot \mathrm{k},
$$

where $\mathrm{k}$ is the number of groups and $\mathrm{n}$ is the number of observations in a group. The sum of the standard deviations $\left(\mathrm{VKO}_{\mathrm{s}}\right)$ was calculated as in Equation (4):

$$
\mathrm{VKO}_{\mathrm{s}}=\left(\sum_{\mathrm{j}=1}^{\mathrm{k}} \sum_{\mathrm{i}=1}^{\mathrm{n}} \mathrm{X}_{\mathrm{ij}}\right)^{2}-\mathrm{c} .
$$

Meanwhile, the average between the groups $\mathrm{VKO}_{\mathrm{p}}$ was defined as in Equation (5):

$$
\mathrm{VKO}_{\mathrm{p}}=\left(\sum_{\mathrm{j}=1} \sum_{\mathrm{l}=1} \mathrm{x}_{\mathrm{ij}}\right)^{2} / \mathrm{n}-\mathrm{c} .
$$

In addition, the average between the groups $\mathrm{VKO}_{z}$ was defined as in Equation (6):

$$
\mathrm{VKO}_{\mathrm{z}}=\mathrm{VKO}_{\mathrm{s}}-\mathrm{VKO}_{\mathrm{p}}
$$

Finally, the assessment of variance $s^{2}$ was conducted as in Equations (7) and (8) in the following circumstances:

(i) between the group averages:

$$
\mathrm{s}_{\mathrm{p}}^{2}=\mathrm{VKO} / \mathrm{k}-1,
$$

(ii) within the groups:

$$
\mathrm{s}_{\mathrm{z}}^{2}=\mathrm{VKO}_{\mathrm{z}} / \mathrm{k} \cdot(\mathrm{n}-1) .
$$

\subsection{Samples and Technology: A Process}

Food's thermal processing includes all those thermal, mechanical, and physical processes that make the food edible. Heat causes various chemical and physical changes in food. Heat-treated foods become more easily digestible than raw foods, which is essential for some foods. The sensory properties of the foods also change. Cooking creates new flavours. For example, muscle fibres in meat harden, and connective tissue softens. At the same time, the heat kills harmful germs and animal parasites, and in some cases, sensitive vitamins are lost, and enzymes are destroyed. Thus, in cooking, the purpose of heat treatment is to achieve suitable consumption characteristics (e.g., colour, texture, and appearance) or gastronomic quality of the food. The culinary classification of thermal processes is dry, moist, combined, and other processes.

Dry thermal processes include baking, grilling, roasting, and deep-frying. They occur at a low partial pressure of water vapour and relatively high temperatures and are most commonly used in practice. Dry processes include a non-enzymatic browning reaction (i.e., 
Maillard reaction), sugar caramelisation, lipid polymerisation, protein-lipid interactions, and the like. This change affects the specific flavour, texture, and colour of the dish. Surface drying occurs, which is also the cause of a crispy crust and the change in pigments. Depending on the type of process, a distinct, specific aroma of the dish is also formed.

The most used wet processes are boiling in water and steaming. Food can be cooked below the boiling point, in a water bath or steamer, moist circulating air, and high-pressure water. The heat mediator is steam or water. The temperatures are lower than in dry processes and do not exceed $100{ }^{\circ} \mathrm{C}$, except in high-pressure cooking. In processes taking place in a humid environment and at relatively low temperatures, there are no browning reactions, no drying of the surface, and no changes in the pigments. The sensory characteristics of the dishes are entirely different from the dry processes (mild aroma). They are helpful for culinary practice and nutrition. Water excretes various soluble substances from foods, such as vitamins, mineral salts, acids, aromatic substances, and more. Therefore, cooking with more water is less recommended for foods rich in vitamins and mineral salts (i.e., vegetables and fruits).

An essential combined process is steaming. In steaming, we make food edible through a combination of dry and wet processes. The mediator is the food's own liquid or added liquid, steam, and fat. There are different types of steaming: stewing in its own juice, with added fat, or with added fat and water. Many ready-made dishes with sauce are prepared this way (e.g., stuffed peppers).

The food is placed in $150-160{ }^{\circ} \mathrm{C}$ fat, and hot water is poured over it several times during braising. The fat, which has a higher temperature than water, softens the food faster and influences new aromatic substances. If we want dishes to bring out the distinct flavour of a particular food, we roast it first. Braising is the best cooking technique for preparing vegetables, meat, and other food, because the nutritional value is only slightly reduced during braising. Soluble substances are eliminated because only a tiny amount of liquid is added to the food. By braising foods in a covered container and stirring as little as possible, we also limit air access to the food, which preserves the vitamins. With steamed foods, the inherent flavours of the food become more pronounced, and the fat forms new flavours.

The most significant changes during heat treatment by cooking are the following: proteins denature, starch swells and then hardens and binds much water, sugar and salt melt, fat partially melts or dissolves, cellulose partially decomposes, colourants change, volatile aromatic compounds evaporate, and vitamins and minerals are lost. The water in which the food is cooked acquires a characteristic flavour and a colouration in leafy vegetables. Vitamins that are sensitive to heat and air are partially degraded. After heat treatment with stewing, the changes are like those after cooking; only the differences in the loss of vitamins and minerals are minor.

Regeneration or reheating of prepared foods occurs at the point of consumption. All heat treatment processes are helpful for regeneration. It is desirable to reach the temperature of consumption as soon as possible. Poor temperature control and overheating can significantly affect the sensory and nutritional quality of the product. Prolonged heating can affect the shelf life of the food. Finished dishes can be heated in an ordinary open pan or oven, either with standard air or circulating air, in steam ovens, in boiling water, by infrared rays and microwaves, or by combining the above methods.

Refrigerated and frozen ready meals must be heated to a core temperature of at least $70^{\circ} \mathrm{C}$ after storage. This temperature is essential for both the edible properties and microbiological integrity. It would be best to heat each type of food separately based on their specific characteristics. This separation is the only way to obtain a dish of the optimal conditions.

\subsubsection{Preparation}

The experiment involved preparing stuffed pepper samples, packing, freezing, storing, and regenerating (heating) the samples. The samples were packed individually according to the sample group and freezing temperature. Plastic containers previously disinfected 
with alcohol were used. The stuffed peppers were frozen in the same containers and later regenerated (in a temperature range from $-50^{\circ} \mathrm{C}$ to $+150^{\circ} \mathrm{C}$ ). The samples were frozen and stored in a freezer at a constant temperature of $-18{ }^{\circ} \mathrm{C}$ and $-25^{\circ} \mathrm{C}$. The temperature in the freezer was monitored regularly. Analyses were performed on samples of freshly stuffed peppers (immediately after preparation) after heat regenerated the samples at 1 month and 2 months of storage (freezing at two different temperatures) $\left(-18{ }^{\circ} \mathrm{C}\right.$ and $\left.-25^{\circ} \mathrm{C}\right)$.

The stuffed peppers were prepared by cooking a mixture of rice and meat with spices and roasted onions. The stuffing was placed into hollowed-out peppers and heat-treated by a combination of frying (roasting the peppers) and stewing with the addition of a small amount of water. Separately, a sauce was prepared from the listed ingredients (oil, sugar, tomatoes and puree, and flour). The heat treatment time was 14 minutes. Cooking took place at temperatures of $93-147^{\circ} \mathrm{C}$. Regeneration of the samples was carried out in a convection oven of the company Zanussi (Italy), with gas installation performed according to the ratio of propane/butane G $201.1 \mathrm{~m}^{3} / \mathrm{h}$ and oven power of $190 \mathrm{~W}$. The core temperature of each heated sample was at least $70{ }^{\circ} \mathrm{C}$ after being measured with a thermometer installed in the oven within 26 minutes. Regeneration was carried out according to a regeneration programme (i.e., with a mixture of dry and humid air). The temperature of the heated air was $120^{\circ} \mathrm{C}$. For sensory analysis, the samples for each tester were portioned separately onto the same plates and pre-heated to $31^{\circ} \mathrm{C}$.

\subsubsection{The Recipe and Nutritional Values}

The raw materials for the task were culinary prepared peppers according to the appropriate recipe. The ingredients were fresh peppers, pork and beef, fat, onions, rice, salt, garlic, spices (marjoram, parsley, and pepper), sugar, tomato puree, and tomatoes (Table 2). The very name of the dish tells us that the peppers in stuffed peppers are one of the essential ingredients of the dish, without which it would not exist. To a large extent, tomatoes are also included in the dish. They add a unique colour and flavour to the dishes. The dish is harmonised with the taste of onions, garlic, sugar, green spices, and salt.

Table 2. Ingredients for stuffed peppers.

\begin{tabular}{ccc}
\hline Food & Quantity (dag) & The Proportion of Ingredients (\%) \\
\hline yellow peppers & 210 & 57.07 \\
\hline pork & 15 & 4.08 \\
\hline beef & 25 & 6.79 \\
\hline fat & 8 & 2.17 \\
\hline onions & 4 & 1.09 \\
\hline rice & 16 & 4.35 \\
\hline salt & 1 & 0.27 \\
\hline garlic & 0.5 & 0.001 \\
\hline spices & 1 & 0.27 \\
\hline sugar & 1 & 0.27 \\
\hline tomato puree & 12 & 3.26 \\
\hline tomatoes & 75 & 20.38 \\
\hline together & 368.5 & 100.001 \\
\hline
\end{tabular}

Starchy sauces play an essential role in the preparation of dishes and meals. This includes the famous tomato sauce. If wheat flour is used as a thickener, it must be well sealed, or the sauce will taste like raw flour. Such sauces also often have the problem of an inhomogeneous structure; that is, lumps are formed, which is a technical defect. Sauces that use flour as a thickening agent in the form of roasting have several disadvantages. 
These include longer preparation time, poor homogeneity, and instability during heating, freezing, and storage. Deteriorated stability manifests itself in phase separation, flaking, and the separation of fat and water. Therefore, experts are developing new technologies to prepare sauces, replacing wheat flour with modified starches. The results of numerous studies [67-70] have shown that the use of modified starch leads to better homogeneity and consistency in sauces, reduces preparation time, provides thermal stability, and prevents phase separation (fat). All this indirectly creates minor changes in the sensory properties of sauces [70].

The filling in stuffed peppers consists of minced meat with rice and toppings. Minced meat is widely used in culinary practice. However, because of the large surface area of the meat, which affects the microbiological integrity, we must be careful. This carefulness means that freezing chops is more challenging than freezing significant cuts of meat. The starch conversion process and rancidity are more pronounced when starchy foods are added to minced meat, unless additives are added to prevent rancidity.

The nutritional values of the stuffed peppers based on the recipe in Table 2 were generated using software registered at the Slovenian Intellectual Property Office. The values are listed in Appendix $C$ and correspond to the energy value per $100 \mathrm{~g}: 266 \mathrm{~kJ} / 64 \mathrm{kcal}$, fat $=2.4 \mathrm{~g}$, saturated $=1 \mathrm{~g}$, carbohydrates $=6.9 \mathrm{~g}$, of which sugar is $1.8 \mathrm{~g}$, protein $=3.4 \mathrm{~g}$, and salt $=0.3 \mathrm{~g}$.

\section{Results}

Table 3 shows the basic descriptive statistical parameters for the 63 stuffed pepper samples analysed for the sensory characteristics. It shows the average of all three samples for a given sensory property. The coefficient of variation shows the most significant deviation from the average. The highest deviation was recognised for the characteristics of the (1) stickiness of the filling, (2) aftertaste of the peppers, and (3) fat content of the samples. Nevertheless, the data show the mean values of the sensory analysis of all samples in three periods and at two different storage temperatures. In addition, the minimum and maximum values are presented. Finally, the standard deviations for the peppers (the overall impression of the dish), the sauce, the filling of the peppers, and the whole dish are visible in Table 3.

Table 4 shows the average proportions of the three evaluators for each of the sensory properties of the stuffed pepper samples. The results show that the samples' storage time (freezing) had the most significant influence on the sensory properties, while the different storage temperatures had a negligible influence. Compared with the fresh samples, the sensory characteristics of the sauce deteriorated, especially after storage, as the ratings were lower. Monitoring the quality of the filling showed greater stickiness and compactness of the filling and poorer aroma. Finally, a poorer overall acceptance of the whole dish was observed after 2 months, regardless of the storage temperature.

Table 5 shows the sources of variability and statistical characteristics of their influence on the sensory characteristics of the stuffed peppers. The results show that the temperature and freezing had the most significant influence on the changes in the sensory properties. Due to the most significant influence, the combination $\mathrm{T} \cdot \mathrm{Z}$ was used, and their influence is displayed in the following tables and the most distinctive differences in the diagrams.

Table 3. Basic descriptive statistical parameters of stuffed peppers.

\begin{tabular}{ccccccc}
\hline Parameter & $\mathbf{n}$ & $\boldsymbol{\mu}$ & Min & Max & SD & KV (\%) \\
\hline & peppers & (overall impression of the dish) & & & & \\
smell (1-7) & 63 & 5.8 & 3.0 & 7.0 & 1.1 & 18.5 \\
foreign smells (1-7) & 63 & 1.3 & 1.0 & 3.0 & 0.4 & 34.0 \\
appearance of the dish (1-7) & 63 & 5.6 & 3.0 & 6.5 & 0.9 & 15.4 \\
colour (1-7) & 63 & 6.1 & 4.5 & 7.0 & 0.9 & 13.9 \\
\hline
\end{tabular}


Table 3. Cont.

\begin{tabular}{|c|c|c|c|c|c|c|}
\hline Parameter & $\mathbf{n}$ & $\mu$ & Min & Max & SD & KV (\%) \\
\hline \multicolumn{7}{|c|}{ sauce } \\
\hline sauce colour (1-7) & 63 & 6.0 & 4.0 & 7.0 & 0.9 & 15.6 \\
\hline sauce stability (1-7) & 63 & 5.9 & 4.0 & 7.0 & 1.0 & 17.4 \\
\hline gloss sauce $(1-7)$ & 63 & 5.9 & 2.0 & 7.0 & 1.1 & 18.5 \\
\hline aroma of sauce $(1-7)$ & 63 & 5.8 & 2.5 & 7.0 & 1.2 & 20.2 \\
\hline feeling of sweetness in the mouth (1-7) & 63 & 5.8 & 1.0 & 7.5 & 1.3 & 22.0 \\
\hline homogeneity (1-7) & 63 & 5.8 & 2.0 & 7.0 & 1.1 & 18.3 \\
\hline thickness $(1-4-7)$ & 63 & 3.6 & 2.5 & 5.0 & 0.6 & 15.7 \\
\hline \multicolumn{7}{|c|}{ stuffing } \\
\hline cross-sectional color (1-7) & 63 & 5.5 & 3.0 & 6.5 & 0.8 & 14.6 \\
\hline cross-sectional composity (1-7) & 63 & 5.7 & 3.5 & 7.0 & 0.9 & 15.6 \\
\hline lightness and compression (1-7) & 63 & 5.7 & 4.0 & 7.0 & 0.6 & 10.9 \\
\hline sticky stuffing (1-7) & 63 & 2.4 & 1.0 & 5.0 & 1.2 & 49.3 \\
\hline fat $(1-7)$ & 63 & 1.4 & 1.0 & 2.5 & 0.5 & 35.9 \\
\hline pepper flavour (1-7) & 63 & 5.6 & 4.0 & 6.5 & 0.8 & 14.0 \\
\hline pepper tastes (1-7) & 63 & 1.4 & 1.0 & 3.0 & 0.5 & 39.0 \\
\hline \multicolumn{7}{|c|}{ the whole dish } \\
\hline taste $(1-7)$ & 63 & 1.3 & 1.0 & 2.5 & 0.5 & 36.2 \\
\hline feel in the mouth (1-7) & 63 & 5.3 & 3.0 & 6.5 & 0.9 & 16.0 \\
\hline salt (1-4-7) & 63 & 3.7 & 2.0 & 4.5 & 0.5 & 12.7 \\
\hline aroma harmony $(1-7)$ & 63 & 5.5 & 3.5 & 7.0 & 0.9 & 15.5 \\
\hline overall impression (1-7) & 63 & 5.5 & 4.0 & 6.5 & 0.9 & 15.5 \\
\hline
\end{tabular}

Note: $\mathrm{n}=$ number of samples; $\mu=$ average value; $\mathrm{Min}=$ minimum value; $\mathrm{Max}=$ maximum value; $\mathrm{SD}=$ standard deviation; $\mathrm{KV}=$ coefficient of variability $(\%)$.

Table 4. Average estimates of sensory properties of stuffed peppers as a function of storage conditions.

\begin{tabular}{|c|c|c|c|c|c|}
\hline $\begin{array}{c}\text { Parameter } \\
\text { Storage Temperature }\end{array}$ & 0 & $\begin{array}{c}1 \\
-18^{\circ} \mathrm{C} \\
\end{array}$ & $\begin{array}{c}2 \\
-18^{\circ} \mathrm{C} \\
\end{array}$ & $\begin{array}{c}1 \\
-25^{\circ} \mathrm{C} \\
\end{array}$ & $\begin{array}{c}2 \\
-25^{\circ} \mathrm{C} \\
\end{array}$ \\
\hline \multicolumn{6}{|c|}{ peppers (overall impression of the dish) } \\
\hline smell (1-7) & 6.7 & 5.3 & 4.9 & 5.8 & 4.6 \\
\hline foreign smells (1-7) & 1.2 & 1.5 & 1.1 & 1.5 & 1.2 \\
\hline appearance of the dish (1-7) & 5.5 & 5.5 & 4.4 & 5.6 & 5.1 \\
\hline colour $(1-7)$ & 6.9 & 5.9 & 5.1 & 5.8 & 5.2 \\
\hline \multicolumn{6}{|c|}{ sauce } \\
\hline sauce colour (1-7) & 6.7 & 5.8 & 4.9 & 5.9 & 5.1 \\
\hline sauce stability (1-7) & 6.7 & 5.7 & 4.9 & 5.8 & 4.5 \\
\hline gloss sauce $(1-7)$ & 6.7 & 5.4 & 4.8 & 5.6 & 5.0 \\
\hline aroma of sauce $(1-7)$ & 6.8 & 5.2 & 4.9 & 5.7 & 4.5 \\
\hline feeling of sweetness in the mouth $(1-7)$ & 6.6 & 4.8 & 5.0 & 5.6 & 4.6 \\
\hline homogeneity $(1-7)$ & 6.8 & 4.9 & 5.1 & 5.5 & 4.9 \\
\hline thickness $(1-4-7)$ & 3.8 & 3.4 & 3.1 & 4.0 & 3.1 \\
\hline \multicolumn{6}{|c|}{ stuffing } \\
\hline cross-sectional colour $(1-7)$ & 6.1 & 5.3 & 4.6 & 5.5 & 5.4 \\
\hline cross-sectional composity (1-7) & 6.5 & 5.1 & 4.9 & 5.5 & 5.1 \\
\hline lightness and compression (1-7) & 6.1 & 5.1 & 5.1 & 5.9 & 4.5 \\
\hline sticky stuffing $(1-7)$ & 1.4 & 2.6 & 4.1 & 2.3 & 3.8 \\
\hline fat $(1-7)$ & 1.0 & 1.6 & 1.5 & 1.4 & 2.0 \\
\hline pepper flavour (1-7) & 6.3 & 5.4 & 4.7 & 5.6 & 4.6 \\
\hline pepper tastes $(1-7)$ & 1.0 & 1.3 & 1.9 & 1.3 & 2.0 \\
\hline \multicolumn{6}{|c|}{ the whole dish } \\
\hline taste $(1-7)$ & 5.9 & 5.2 & 4.7 & 5.3 & 4.2 \\
\hline feel in the mouth (1-7) & 1.0 & 1.2 & 1.1 & 1.2 & 1.7 \\
\hline salt $(1-4-7)$ & 3.8 & 3.8 & 3.5 & 3.7 & 3.3 \\
\hline aroma harmony (1-7) & 6.2 & 5.4 & 4.6 & 5.6 & 4.4 \\
\hline overall impression (1-7) & 6.3 & 5.1 & 4.7 & 5.5 & 4.5 \\
\hline
\end{tabular}

Note. $0=$ comparative sample (immediately after preparation); 1 = after the first month of storage; 2 = after the second month. 
Table 5. Sources of variability and statistical characteristics of their influence on the sensory properties of stuffed peppers.

\begin{tabular}{|c|c|c|c|c|c|c|}
\hline Parameter & \multicolumn{6}{|c|}{ Variability ( $p$-Values) } \\
\hline \multirow{3}{*}{ Degrees of Freedom } & Z & $\mathrm{T}$ & S & $\mathrm{O}$ & $Z^{*} \mathrm{~T}$ & \multirow{2}{*}{ Rsd } \\
\hline & 2 & 2 & 2 & 2 & 2 & \\
\hline & \multicolumn{6}{|c|}{ peppers (overall impression of the dish) } \\
\hline smell (1-7) & 0.0092 & 0.0001 & 0.0001 & 0.1770 & 0.0041 & 0.53 \\
\hline foreign smells (1-7) & 0.0741 & 0.2635 & 0.0001 & 0.1387 & 0.2635 & 0.35 \\
\hline appearance of the dish (1-7) & 0.0003 & 0.0001 & 0.0001 & 0.2977 & 0.0089 & 0.50 \\
\hline colour $(1-7)$ & 0.0001 & 0,0001 & 0.0001 & 0.0085 & 0.0005 & 0.34 \\
\hline \multicolumn{7}{|c|}{ sauce } \\
\hline sauce colour (1-7) & 0.0001 & 0.0001 & 0.0001 & 0.8174 & 0.0005 & 0.37 \\
\hline sauce stability (1-7) & 0.0003 & 0.0001 & 0.0024 & 0.0210 & 0.0052 & 0.56 \\
\hline gloss sauce $(1-7)$ & 0.0315 & 0.0001 & 0.0001 & 0.7165 & 0.1535 & 0.56 \\
\hline aroma of sauce $(1-7)$ & 0.0467 & 0.0001 & 0.0001 & 0.8168 & 0.0290 & 0.64 \\
\hline $\begin{array}{l}\text { feeling of sweetness in the mouth } \\
\qquad(1-7)\end{array}$ & 0.4667 & 0.0001 & 0.0001 & 0.3438 & 0.0405 & 0.71 \\
\hline homogeneity (1-7) & 0.5886 & 0.0001 & 0.0001 & 0.1465 & 0.0748 & 0.53 \\
\hline thickness $(1-4-7)$ & 0.0010 & 0.0070 & 0.0001 & 0.1419 & 0.0155 & 0.39 \\
\hline \multicolumn{7}{|c|}{ stuffing } \\
\hline cross-sectional colour (1-7) & 0.0025 & 0.0001 & 0.0001 & 0.7341 & 0.0418 & 0.41 \\
\hline cross-sectional composity (1-7) & 0.2206 & 0.0001 & 0.0036 & 0.0501 & 0.4583 & 0.50 \\
\hline lightness and compression (1-7) & 0.0003 & 0.0006 & 0.2699 & 0.1605 & 0.0113 & 0.46 \\
\hline sticky stuffing (1-7) & 0.0001 & 0.0001 & 0.0001 & 0.2336 & 0.0001 & 0.37 \\
\hline fat $(1-7)$ & 0.1442 & 0.0001 & 0.0393 & 0.0011 & 0.0068 & 0.31 \\
\hline pepper flavour (1-7) & 0.0001 & 0.0001 & 0.0001 & 0.0001 & 0.0001 & 0.30 \\
\hline pepper tastes $(1-7)$ & 0.0001 & 0.0001 & 0.0064 & 0.0023 & 0.0018 & 0.31 \\
\hline \multicolumn{7}{|c|}{ the whole dish } \\
\hline taste (1-7) & 0.0014 & 0.0001 & 0.0651 & 0.0594 & 0.0237 & 0.40 \\
\hline feel in the mouth $(1-7)$ & 0.0001 & 0.0001 & 0.0001 & 0.0431 & 0.0005 & 0.33 \\
\hline salt $(1-4-7)$ & 0.0120 & 0.0191 & 0.0001 & 0.3030 & 0.0705 & 0.29 \\
\hline aroma harmony (1-7) & 0.0001 & 0.0001 & 0.0001 & 0.3622 & 0.0001 & 0.39 \\
\hline overall impression (1-7) & 0.0001 & 0.0001 & 0.0001 & 0.9508 & 0.0001 & 0.28 \\
\hline
\end{tabular}

Note. Rsd $=$ residual balance; $\mathrm{Z}=$ freezing; $\mathrm{T}=$ freezing temperature; $\mathrm{S}=$ batch; $\mathrm{O}=$ taster.

The following tables contain the least squares means (LSM), standard errors of the mean (SEM), and the significance level of the effect of the freezing temperature and period. Table 6 shows that the temperature significantly affected some of the sensory characteristics of the stuffed peppers. Most noticeable was the mouthfeel of the sauce, which became less smooth and even sticky due to freezing. A more noticeable change can also be observed in the smell, which deteriorated considerably since the first analysis of the fresh peppers, especially after storage at $\mathrm{T}=-18^{\circ} \mathrm{C}$. A significant deterioration of the aroma of the sauce, which lost intensity, was also observed. The overall impression of the peppers after 1 month of freezing was underestimated. These are the results of the deterioration of the sensory properties. Finally, the differences between the standard samples (freshly prepared stuffed peppers) and those after 1 month of storage at $-18{ }^{\circ} \mathrm{C}$ are statistically significant. The identified factors were the smell, density of the sauce, composition of the filling, stickiness, and aroma in the overall impression of the peppers.

According to the data presented in Table 7, the sensory properties deteriorated further after 2 months of storage. Thus, the deterioration of the odour, sauce stability, aroma, homogeneity, and mouthfeel were more significant at a lower freezing temperature. The differences in most sensory properties (between storage temperatures) were statistically of high significance. The differences in the stickiness of the filling, which increased strongly after 2 months of freezing at both storage temperatures, was most evident. 
Table 6. Influence of freezing temperature on sensory properties of stuffed pepper samples after 1 month of freezing.

\begin{tabular}{|c|c|c|c|c|c|}
\hline \multirow[b]{2}{*}{ Parameter } & \multirow[b]{2}{*}{$\mathbf{T}$} & \multirow[b]{2}{*}{ LSM } & \multirow[b]{2}{*}{ SEM } & \multicolumn{2}{|c|}{ Groups Differences } \\
\hline & & & & $-18{ }^{\circ} \mathrm{C}$ & $-25^{\circ} \mathrm{C}$ \\
\hline \multicolumn{6}{|c|}{ peppers (overall impression of the dish) } \\
\hline \multirow{3}{*}{ smell (1-7) } & standard & 6.7 & 0.29 & $1.6^{* * *}$ & $0.9 *$ \\
\hline & $-18^{\circ} \mathrm{C}$ & 5.1 & 0.29 & & -0.7 \\
\hline & $-25^{\circ} \mathrm{C}$ & 5.8 & 0.29 & & \\
\hline \multirow{4}{*}{ colour (1-7) } & standard & 6.9 & 0.19 & 1.0 ** & $0.8^{* *}$ \\
\hline & $-18^{\circ} \mathrm{C}$ & 5.9 & 0.19 & & -0.2 \\
\hline & $-25^{\circ} \mathrm{C}$ & 6.1 & 0.19 & & \\
\hline & \multicolumn{5}{|c|}{ sauce } \\
\hline \multirow{3}{*}{ sauce stability (1-7) } & standard & 6.7 & 0.25 & 1.0 ** & $0.9 *$ \\
\hline & $-18^{\circ} \mathrm{C}$ & 5.7 & 0.25 & & -0.1 \\
\hline & $-25^{\circ} \mathrm{C}$ & 5.8 & 0.25 & & \\
\hline \multirow{3}{*}{ gloss sauce (1-7) } & standard & 6.8 & 0.36 & $1.4^{*}$ & $1.2^{*}$ \\
\hline & $-18^{\circ} \mathrm{C}$ & 5.4 & 0.36 & & -0.2 \\
\hline & $-25^{\circ} \mathrm{C}$ & 5.6 & 0.36 & & \\
\hline \multirow{4}{*}{ aroma of sauce (1-7) } & standard & 6.8 & 0.38 & $1.6^{* *}$ & $1.1 *$ \\
\hline & $-18^{\circ} \mathrm{C}$ & 5.2 & 0.38 & & -0.5 \\
\hline & $-25^{\circ} \mathrm{C}$ & 5.7 & 0.38 & & \\
\hline & standard & 6.8 & 0.42 & $2.0 *$ & 1.2 \\
\hline \multirow{3}{*}{ feeling of sweetness in the mouth (1-7) } & $-18^{\circ} \mathrm{C}$ & 4.8 & 0.42 & & -0.8 \\
\hline & $-25^{\circ} \mathrm{C}$ & 5.6 & 0.42 & & \\
\hline & standard & 6.8 & 0.31 & 1.9 & $1.3^{* *}$ \\
\hline \multirow[t]{3}{*}{ homogeneity (1-7) } & $-18^{\circ} \mathrm{C}$ & 4.9 & 0.31 & & -0.6 \\
\hline & $-25^{\circ} \mathrm{C}$ & 5.5 & 0.31 & & \\
\hline & standard & 3.8 & 0.15 & $0.2^{* * *}$ & -0.1 \\
\hline \multirow{3}{*}{ thickness $(1-4-7)$} & $-18^{\circ} \mathrm{C}$ & 3.6 & 0.15 & & -0.3 \\
\hline & $-25^{\circ} \mathrm{C}$ & 3.9 & 0.15 & & \\
\hline & & & & & \\
\hline \multirow{4}{*}{ cross-sectional colour (1-7) } & standard & 6.1 & 0.22 & $0.9^{* *}$ & $0.7^{*}$ \\
\hline & $-18^{\circ} \mathrm{C}$ & 5.2 & 0.22 & & -0.2 \\
\hline & $-25^{\circ} \mathrm{C}$ & 5.4 & 0.22 & & \\
\hline & standard & 6.5 & 0.18 & $1.4^{* * *}$ & $0.0^{* * *}$ \\
\hline \multirow{2}{*}{ cross-sectional composity (1-7) } & $-18^{\circ} \mathrm{C}$ & 5.1 & 0.18 & & -1.4 \\
\hline & $-25^{\circ} \mathrm{C}$ & 6.5 & 0.18 & & \\
\hline \multirow{4}{*}{ sticky stuffing (1-7) } & standard & 1.3 & 0.13 & $-1.3 * * *$ & $-1.0 * * *$ \\
\hline & $-18^{\circ} \mathrm{C}$ & 2.6 & 0.13 & & 0.3 \\
\hline & $-25^{\circ} \mathrm{C}$ & 2.3 & 0.11 & & \\
\hline & standard & 1.0 & 0.11 & $-0.6^{* *}$ & $-0.4 *$ \\
\hline fat $(1-7)$ & $-18^{\circ} \mathrm{C}$ & 1.6 & 0.11 & & 0.2 \\
\hline & $-25^{\circ} \mathrm{C}$ & 1.4 & 0.11 & & \\
\hline & standard & 6.3 & 0.15 & $0.9^{* * *}$ & $0.7^{* *}$ \\
\hline pepper flavour (1-7) & $-18^{\circ} \mathrm{C}$ & 5.4 & 0.15 & & -0.2 \\
\hline & $-25^{\circ} \mathrm{C}$ & 5.6 & 0.15 & & \\
\hline & standard & 1.0 & 0.10 & $-0.3 *$ & -0.3 \\
\hline pepper taste $(1-7)$ & $-18^{\circ} \mathrm{C}$ & 1.3 & 0.10 & & 0.0 \\
\hline & $-25^{\circ} \mathrm{C}$ & 1.3 & 0.10 & & \\
\hline & the & & & & \\
\hline & standard & 5.9 & 0.23 & $0.7^{*}$ & 0.6 \\
\hline feel in the mouth (1-7) & $-18^{\circ} \mathrm{C}$ & 5.2 & 0.23 & & -0.1 \\
\hline & $-25^{\circ} \mathrm{C}$ & 5.3 & 0.23 & & \\
\hline & standard & 6.2 & 0.21 & $0.8^{*}$ & 0.6 \\
\hline aroma harmony (1-7) & $-18^{\circ} \mathrm{C}$ & 5.4 & 0.21 & & -0.2 \\
\hline & $-25^{\circ} \mathrm{C}$ & 5.6 & 0.21 & & \\
\hline & standard & 6.3 & 0.19 & $1.2^{* * *}$ & 0.8 ** \\
\hline overall impression (1-7) & $-18^{\circ} \mathrm{C}$ & 5.1 & 0.19 & & -0.4 \\
\hline & $-25^{\circ} \mathrm{C}$ & 5.5 & 0.19 & & \\
\hline
\end{tabular}

Note. $p \leq 0.001 .{ }^{* * *}$ Very high statistical significance at more than $0.1 \% ; p \leq 0.01 .{ }^{* *}$ High statistical significance at more than $1 \% ; p \leq 0.05$. * Statistically significant at more than $5 \%$. LSM = least squares means; SEM = standard errors of the mean; $\mathrm{T}=$ freezing temperature; standard $=$ fresh batch.

Table 8 reveals the effect of the duration of freezing at $-18{ }^{\circ} \mathrm{C}$ on the individual sensory properties of the stuffed peppers. The difference in the stickiness of the stuffing was statistically very high. This consequence was probably due to excessive swelling of the starch and a consequent increase in stickiness. The change in the aroma was also significant, as no more characteristic aroma was detected after the stuffed peppers were compared 
with the freshly prepared peppers. In addition to the above properties, the stability of the sauce also changed significantly.

Table 7. Influence of freezing temperature on sensory properties of stuffed pepper samples after 2 months of freezing.

\begin{tabular}{|c|c|c|c|c|c|}
\hline \multirow[b]{2}{*}{ Parameter } & \multirow[b]{2}{*}{$\mathbf{T}$} & \multirow[b]{2}{*}{ LSM } & \multirow[b]{2}{*}{ SEM } & \multicolumn{2}{|c|}{ Groups Differences } \\
\hline & & & & $-18^{\circ} \mathrm{C}$ & $-25^{\circ} \mathrm{C}$ \\
\hline \multicolumn{6}{|c|}{ peppers (overall impression of the dish) } \\
\hline \multirow{4}{*}{ smell (1-7) } & standard & 6.7 & 0.18 & $1.8^{* * *}$ & $2.1 * * *$ \\
\hline & $-18{ }^{\circ} \mathrm{C}$ & 4.9 & 0.18 & & 0.3 \\
\hline & $-25^{\circ} \mathrm{C}$ & 4.6 & 0.18 & & \\
\hline & standard & 6.1 & 0.25 & $1.7^{* * *}$ & 1.0 ** \\
\hline \multirow[t]{3}{*}{ the appearance of the dish (1-7) } & $-18^{\circ} \mathrm{C}$ & 4.4 & 0.25 & & -0.7 \\
\hline & $-25^{\circ} \mathrm{C}$ & 5.1 & 0.25 & & \\
\hline & standard & 6.9 & 0.13 & $1.8^{* * *}$ & $1.7 * * *$ \\
\hline \multirow[t]{4}{*}{ colour (1-7) } & $-18^{\circ} \mathrm{C}$ & 5.1 & 0.13 & & -0.2 \\
\hline & $-25^{\circ} \mathrm{C}$ & 5.2 & 0.13 & & \\
\hline & (n) & & & & \\
\hline & standard & 6.7 & 0.20 & $1.8^{* * *}$ & $1.6^{* * *}$ \\
\hline \multirow{3}{*}{ sauce colour (1-7) } & $-18^{\circ} \mathrm{C}$ & 4.9 & 0.20 & & -0.2 \\
\hline & $-25^{\circ} \mathrm{C}$ & 5.1 & 0.20 & & \\
\hline & standard & 6.7 & 0.16 & $1.8^{* * *}$ & $2.1^{* * *}$ \\
\hline \multirow[t]{3}{*}{ sauce stability $(1-7)$} & $-18^{\circ} \mathrm{C}$ & 4.9 & 0.16 & & 0.3 \\
\hline & $-25^{\circ} \mathrm{C}$ & 4.6 & 0.16 & & \\
\hline & standard & 6.8 & 0.11 & $2.0^{* * *}$ & $1.9^{* * *}$ \\
\hline \multirow{3}{*}{ gloss sauce (1-7) } & $-18^{\circ} \mathrm{C}$ & 4.8 & 0.11 & & -0.1 \\
\hline & $-25^{\circ} \mathrm{C}$ & 4.9 & 0.11 & & \\
\hline & standard & 6.8 & 0.12 & $1.9^{* * *}$ & $2.2 * * *$ \\
\hline aroma of sauce (1-7) & $-18^{\circ} \mathrm{C}$ & 4.9 & 0.12 & & 0.3 \\
\hline & $-25^{\circ} \mathrm{C}$ & 4.6 & 0.12 & & \\
\hline & standard & 6.8 & 0.17 & $1.8^{* * *}$ & $2.2 * * *$ \\
\hline feeling of sweetness in the mouth (1-7) & $-18^{\circ} \mathrm{C}$ & 5.0 & 0.17 & & 0.4 \\
\hline & $-25^{\circ} \mathrm{C}$ & 4.6 & 0.17 & & \\
\hline & standard & 6.8 & 0.09 & $1.7^{* * *}$ & $1.9^{* * *}$ \\
\hline homogeneity (1-7) & $-18^{\circ} \mathrm{C}$ & 5.1 & 0.09 & & 0.2 \\
\hline & $-25^{\circ} \mathrm{C}$ & 4.9 & 0.09 & & \\
\hline & standard & 3.8 & 0.16 & $0.7 * *$ & $0.7^{* *}$ \\
\hline thickness (1-4-7) & $-18^{\circ} \mathrm{C}$ & 3.1 & 0.16 & & 0.0 \\
\hline & $-25^{\circ} \mathrm{C}$ & 3.1 & 0.16 & & \\
\hline & standard & & 10 & $15^{* * *}$ & \\
\hline cross-sectional colour (1-7) & $\begin{array}{c}\text { standard } \\
-18^{\circ} \mathrm{C}\end{array}$ & $\begin{array}{l}6.1 \\
4.6\end{array}$ & 0.19 & $1.5^{* *+*}$ & $\begin{array}{c}1.3 * * * \\
-0.2\end{array}$ \\
\hline & $-25^{\circ} \mathrm{C}$ & 4.8 & 0.19 & & \\
\hline & standard & 6.5 & 0.20 & $1.8^{* * *}$ & $1.4^{* * *}$ \\
\hline cross-sectional composity (1-7) & $-18^{\circ} \mathrm{C}$ & 4.7 & 0.20 & & -0.4 \\
\hline & $-25^{\circ} \mathrm{C}$ & 5.1 & 0.20 & & \\
\hline & standard & 6.0 & 0.11 & $0.9^{* * *}$ & $1.0^{* * *}$ \\
\hline lightness and compression (1-7) & $-18^{\circ} \mathrm{C}$ & 5.1 & 0.11 & & -0.9 \\
\hline & $-25^{\circ} \mathrm{C}$ & 5.0 & 0.11 & & \\
\hline & standard & 1.3 & 0.16 & $-2.8 * * *$ & $-2.5^{* * *}$ \\
\hline sticky stuffing (1-7) & $-18{ }^{\circ} \mathrm{C}$ & 4.1 & 0.16 & & 0.3 \\
\hline & $-25^{\circ} \mathrm{C}$ & 3.8 & 0.16 & & \\
\hline & standard & 1.0 & 0.11 & $-0.55 * *$ & $-1.0 * * *$ \\
\hline fat $(1-7)$ & $-18^{\circ} \mathrm{C}$ & 1.5 & 0.11 & & -0.5 \\
\hline & $-25^{\circ} \mathrm{C}$ & 2.0 & 0.11 & & \\
\hline & standard & 6.3 & 0.12 & $1.6^{* * *}$ & $1.7^{* * *}$ \\
\hline pepper flavour (1-7) & $-18^{\circ} \mathrm{C}$ & 4.7 & 0.12 & & 0.1 \\
\hline & $-25^{\circ} \mathrm{C}$ & 4.6 & 0.12 & & \\
\hline & standard & 1.0 & 0.13 & $-0.9 * * *$ & $-1.0 * * *$ \\
\hline pepper taste (1-7) & $-18^{\circ} \mathrm{C}$ & 1.9 & 0.13 & & -0.01 \\
\hline & $-25^{\circ} \mathrm{C}$ & 2.0 & 0.13 & & \\
\hline & the & & & & \\
\hline & standard & 1.0 & 0.13 & $-0.8^{* * *}$ & $-0.7^{* *}$ \\
\hline taste $(1-7)$ & $-18^{\circ} \mathrm{C}$ & 1.8 & 0.13 & & 0.1 \\
\hline & $-25^{\circ} \mathrm{C}$ & 1.7 & 0.13 & & \\
\hline & standard & 5.9 & 0.19 & $1.2^{* * *}$ & $1.7^{* * *}$ \\
\hline feel in the mouth (1-7) & $-18^{\circ} \mathrm{C}$ & 4.7 & 0.19 & & 0.5 \\
\hline & $-25^{\circ} \mathrm{C}$ & 4.2 & 0.19 & & \\
\hline & standard & 6.2 & 0.13 & $1.6^{* * *}$ & $1.8^{* * *}$ \\
\hline aroma harmony (1-7) & $-18^{\circ} \mathrm{C}$ & 4.6 & 0.13 & & 0.2 \\
\hline & $-25^{\circ} \mathrm{C}$ & 4.4 & 0.13 & & \\
\hline & standard & 6.3 & 0.11 & $1.6^{* * *}$ & $1.8 * * *$ \\
\hline overall impression (1-7) & $-18^{\circ} \mathrm{C}$ & 4.7 & 0.11 & & 0.2 \\
\hline & $-25^{\circ} \mathrm{C}$ & 4.5 & 0.11 & & \\
\hline
\end{tabular}

Note. $p \leq 0.001 .{ }^{* *}$ Very high statistical significance at more than $0.1 \% ; p \leq 0.01$. ${ }^{* *}$ High statistical significance at more than $1 \% ; p \leq 0.05$. * Statistically significant at more than $5 \%$. LSM = least squares means; SEM = standard errors of the mean; $\mathrm{T}=$ freezing temperature; standard = fresh batch .

Storage of the stuffed peppers at a temperature of $-25{ }^{\circ} \mathrm{C}$ demonstrated slightly less deterioration of the sensory properties than at a temperature of $-18{ }^{\circ} \mathrm{C}$. However, 
the changes can also be observed in Table 9. The results show that the odour, stickiness, and density changed. The differences between 1 and 2 months of storage at $-25^{\circ} \mathrm{C}$ are presented in Table 9. The differences in stickiness, which increased significantly in the pepper filling after 2 months, were statistically very high. A deterioration in the harmony of the aroma of the stuffed peppers was also observed. After 2 months, the sensation in the mouth deteriorated significantly but was still considered acceptable.

Table 8. Effect of freezing at $-18{ }^{\circ} \mathrm{C}$ on the sensory properties of the stuffed peppers (statistically significant differences only).

\begin{tabular}{|c|c|c|c|c|}
\hline Parameter & Group M & LSM & SEM & $\begin{array}{c}\text { Group Differences } \\
2\end{array}$ \\
\hline \multicolumn{5}{|c|}{ peppers (overall impression of the dish) } \\
\hline \multirow{2}{*}{ the appearance of the dish $(1-7)$} & 1 & 5.5 & 0.28 & \multirow[t]{2}{*}{$1.1 *$} \\
\hline & 2 & 4.4 & 0.28 & \\
\hline \multicolumn{5}{|c|}{ sauce } \\
\hline \multirow{2}{*}{ sauce colour $(1-7)$} & 1 & 5.5 & 0.28 & \multirow[t]{2}{*}{$1.1 *$} \\
\hline & 2 & 4.4 & 0.28 & \\
\hline \multirow{2}{*}{ sauce stability (1-7) } & 1 & 5.8 & 0.15 & \multirow[t]{2}{*}{$0.9 * *$} \\
\hline & 2 & 4.9 & 0.15 & \\
\hline \multirow{2}{*}{ thickness (1-4-7) } & 1 & 3.5 & 0.13 & \multirow[t]{2}{*}{0.4 * } \\
\hline & 2 & 3.1 & 0.13 & \\
\hline \multirow{3}{*}{ lightness and compression (1-7) } & & & & \multirow{3}{*}{$0.7^{* * *}$} \\
\hline & 1 & 5.8 & 0.13 & \\
\hline & 2 & 5.1 & 0.13 & \\
\hline \multirow{2}{*}{ sticky stuffing (1-7) } & 1 & 2.6 & 0.14 & \multirow{2}{*}{$-1.5^{* * *}$} \\
\hline & 2 & 4.1 & 0.14 & \\
\hline \multirow{2}{*}{ pepper flavour (1-7) } & 1 & 5.4 & 0.12 & \multirow[t]{2}{*}{$0.7^{* *}$} \\
\hline & 2 & 4.7 & 0.12 & \\
\hline \multirow{2}{*}{ pepper taste $(1-7)$} & 1 & 1.3 & 0.12 & \multirow[t]{2}{*}{$-0.6^{* *}$} \\
\hline & 2 & 1.9 & 0.12 & \\
\hline \multicolumn{5}{|c|}{ the whole dish } \\
\hline \multirow{2}{*}{ taste $(1-7)$} & 1 & 1.2 & 0.14 & \multirow[t]{2}{*}{$-0.6^{* *}$} \\
\hline & 2 & 1.8 & 0.14 & \\
\hline \multirow{2}{*}{ aroma harmony (1-7) } & 1 & 5.4 & 0.20 & \multirow[t]{2}{*}{$0.8 *$} \\
\hline & 2 & 4.6 & 0.20 & \\
\hline
\end{tabular}

Note. $p \leq 0.001 .{ }^{* * *}$ Very high statistical significance at more than $0.1 \% ; p \leq 0.01 .{ }^{* *}$ High statistical significance at more than $1 \% ; p \leq 0.05$.

* Statistically significant at more than $5 \%$. LSM = least squares means; $\mathrm{SEM}=$ standard errors of the mean; $\mathrm{M}=$ month.

Table 9. Effect of freezing at $-25^{\circ} \mathrm{C}$ on the sensory properties of stuffed peppers (statistically significant differences only).

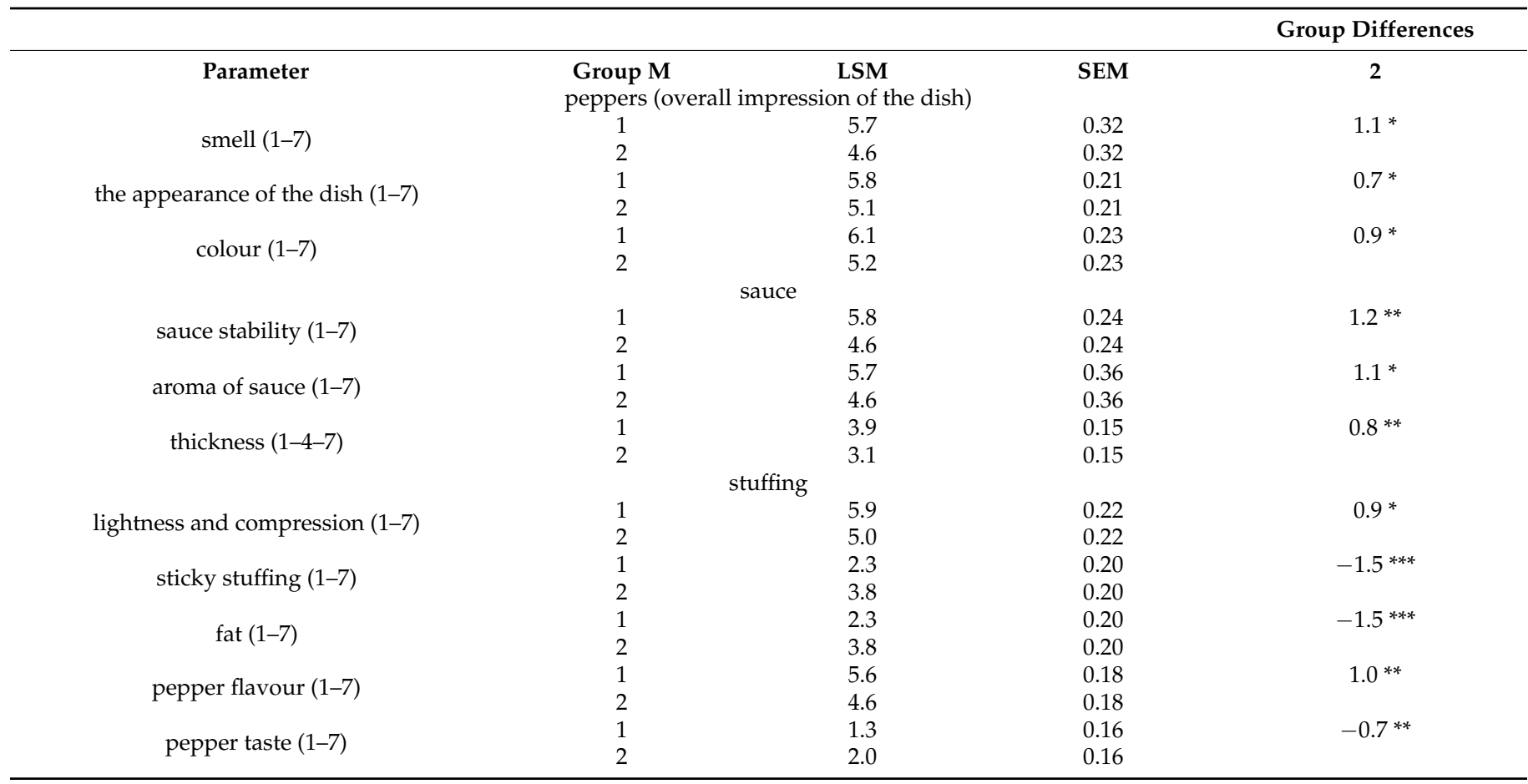


Table 9. Cont.

\begin{tabular}{|c|c|c|c|c|}
\hline & & & & Group Differences \\
\hline Parameter & Group M & LSM & SEM & 2 \\
\hline \multicolumn{5}{|c|}{ the whole dish } \\
\hline \multirow{2}{*}{ feel in the mouth (1-7) } & 1 & 5.3 & 0.24 & \multirow[t]{2}{*}{$0.9^{* *}$} \\
\hline & 2 & 4.2 & 0.24 & \\
\hline \multirow{2}{*}{ aroma harmony (1-7) } & 1 & 5.6 & 0.19 & \multirow[t]{2}{*}{$1.2 * * *$} \\
\hline & 2 & 4.4 & 0.19 & \\
\hline \multirow{2}{*}{ overall impression (1-7) } & 1 & 5.5 & 0.18 & \multirow[t]{2}{*}{$1.0^{* *}$} \\
\hline & 2 & 4.5 & 0.18 & \\
\hline
\end{tabular}

Note. $p \leq 0.001 .{ }^{* * *}$ Very high statistical significance at more than $0.1 \% ; p \leq 0.01 .{ }^{* *}$ High statistical significance at more than $1 \% ; p \leq 0.05$.

* Statistically significant at more than $5 \%$. LSM = least squares means; SEM = standard errors of the mean; M = month.

\section{Discussion}

Heat treatment of food is necessary to maintain microbiological integrity, facilitate digestibility, and develop sensory characteristics that are important for food consumption at home and in the restaurant business, as well as overall in the hospitality industry. All of this affects the quality of the prepared food and sustainable consumption, although there are additional factors, such as improper freezing, which can change the sensory characteristics of the dish.

Freezing is crucial for extending the shelf life of the food. There is considerable research on food and food freezing. However, the area of multi-component or composite dishes has not been well researched, especially in terms of sensory quality and consumption. Such dishes include stuffed peppers. Since various ingredients (e.g., starch, meat, and vegetables) have different heat treatment requirements, it was essential to determine which were the optimum procedures that would ensure the final qualifications of the dish. Light and Walker [71] stated that the sensory characteristics deteriorate due to enzymatic and non-enzymatic reactions in food, oxidation, and microorganism development. When heated slowly to $90^{\circ} \mathrm{C}$, the enzymes can become very active and cause harmful changes in foods. Colour and taste change and foreign odours develop, mainly due to the breakdown of fats, proteins, and carbohydrates. When food is frozen, the formation of ice crystals also causes damage to the cell structure (vegetables). Irrespective of heat recovery, most of the sensory properties of stuffed peppers change immediately after freezing.

Our analyses showed that the initial samples differed, even though they were prepared under the same conditions. This coincidence is one of the reasons why the experiment was carried out in several repetitions. It should be noted that the fresh peppers were of slightly lower quality even in the initial stage, which was due to the quality of the fresh peppers on the market in May. Therefore, in culinary practice, the raw material is essential, but it must always be the basis for the optimally prepared dish offered to the guest, regardless of its origin. Freezing has also contributed to a deterioration in product quality, but not everyone pays attention to that.

Frozen food storage leads to an undesirable odour, water loss due to ice sublimation, starch conversion, protein hydrolysis, and oxidative radiation. The deterioration of the aroma is mainly due to hydrolytic and oxidative reactions in fats and peroxidases in vegetables, limiting the storage time of frozen meals.

Sensory analysis is a good indicator of food quality. In a more comprehensive experiment, it could be complemented by chemical and microbiological analysis. This task aimed to investigate the quality of stuffed peppers under different freezing conditions in terms of sensory quality.

After the first month of freezing, visual changes were already evident, with minor changes in the aroma of the foods except for one sample. After 2 months, the differences were even more remarkable compared with the first month, as the samples emitted a faint, slightly stale smell.

The cross-sectional composition also changed, which was highly rated at the beginning of the experiment. After 2 months of freezing at a higher freezing temperature 
$\left(-18{ }^{\circ} \mathrm{C}\right)$, it was rated just above the acceptable limit, and at a lower temperature $\left(-25^{\circ} \mathrm{C}\right)$, the structure was preserved better. The cross-sectional composition, which had already changed visually, was also associated with the composition, especially with the softened rice. The repeated heat treatments and freezing caused the rice to become sticky and the starch gluten to leak. This ingredient, in turn, also harmed the mouthfeel. The results confirm this, as the differences between the fresh and regenerated frozen peppers were also statistically significant.

The sauce was cloudy (uneven in colour or texture) after regeneration, which was related to the homogeneity of the sauce, which deteriorated considerably regardless of the freezing temperature. Freezing also affected the stability of the tomato sauce as an integral part of the dish. Wheat flour is not the best thickener for frozen dishes, but it also affects the lower density and glossiness of the sauce. Freezing the stuffed peppers also affected the intensity of the flavour and the harmony of flavours. First, the flavour of the peppers changed, and the sauce and filling also tended to deteriorate, leading to aftertastes appearing. Particularly disturbing was the stickiness of the filling in the stuffed pepper samples after being consumed at a lower temperature, which was more pronounced after 2 months. Therefore, it is necessary to consider this when adjusting the heat treatment time during pre-treatment. The repeated treatment has the effect of increasing the starch gluten leakage. In practice, too little attention is often paid to this effect.

The total score of all samples was still above the acceptance level. Objectively, we expected this because 2 months is not yet a critical period for such a dish. Of course, all preparation procedures must be optimal, as well as the procedure for freezing and regeneration. The experiment has shown that specific influences can be handled quite easily in practice. Slightly less time-consuming processing of starchy and frozen dishes and quality starches to thicken sauces can improve the final quality.

If freezing is only used for a short time and maintains the sensory quality, the changes would be minor [72]. However, if we aim for optimal quality, further research and interaction studies are needed, for example, to check the raw materials before processing the study [73].

\section{Conclusions}

\subsection{Main Contributions}

For the contributions to the practice, when ready-to-eat and ready-to-serve foods [74] are of particular interest to the restaurant business, freezing is one of the most sustainable preservation methods that can be used. It helps reduce labour costs, staff shortages, and other process costs during peak times when a restaurant operation suffers from seasonal shocks, during the daily meal period between work breaks, or even during the evening meal peak. Therefore, this study shows that the restaurant business should use sensory analysis more frequently in their operations. Of course, it should be safe because eating out is one of the essential and trendy human social activities. Moreover, food quality is also trendy, and food safety is essential (see Appendix B). The topic of this study was the development of sensory analysis by using the stuffed peppers as an example. The strategy of validating processes is crucial for restaurant managers, owners, and employees.

As for theoretical contributions, looking at the example of stuffed peppers, it could be concluded that freezing deteriorates the quality of dishes. Several factors cause this deterioration. Such analyses in a restaurant business should be a continuous development system. The first perceived feature is decreasing the taste of the sauce (e.g., standard $6.8=$ points (best grade is 7 ), at $-18{ }^{\circ} \mathrm{C}=4.8$ points, and at $-25{ }^{\circ} \mathrm{C}=5.6$ points). The second, higher stickiness of the stuffing after 2 months of freezing (e.g., standard $=1.3$ points (best grade is 1 ), at $-18{ }^{\circ} \mathrm{C}=4.1$ points, and $-25^{\circ} \mathrm{C}=3.8$ points), was recognised Therefore, the duration of freezing was the most critical feature, but higher temperatures also could lead to lower quality. 


\subsection{Summarising the Findings}

In conclusion, restaurant operators should prepare dishes in advance for a strictly specific limited time. Sensory analysis indicated high sensitivity in food preparation, and the hypothesis was confirmed.

This study hypothesised that a long period of freezing significantly reduced the quality of the stuffed peppers. Their quality could also be affected by the storage temperature. Appendix D summarises the results and further explains that the optimum temperature for freezing was $-18^{\circ} \mathrm{C}$, whilst the optimum duration of freezing could not exceed 1 month. All other solutions were not sustainable for storage, while the results of the sensory analysis show that the dish had poorer overall acceptance after the second month, regardless of the freezing temperature. In addition, the recipe allowed for better processing (e.g., for starch or egg ingredients), whilst freezing ready-to-eat food led to cost optimisation.

It is worth noting that the theoretical contribution and SO1 were achieved by examining consumption as a process for achieving long-term, sustainable socioeconomic goals, taking into account extremely important environmental aspects. In addition, $\mathrm{SO} 2$ provided significant data production, as did $\mathrm{SO} 3$ data analysis, with immense contributions to the science of food analysis and practice with its results for the restaurant business.

\subsection{Limitations of the Research}

Some subjective expressions may have played a role in the tasters' decisions. The analysis could highlight, indicate, or determine specific strengths and weaknesses. The strengths could be different backgrounds that provided a broader insight into the sensory analysis, whilst the weaknesses could represent obstacles in the evaluation process. Nevertheless, tasters from the sensory analysis department of the university were engaged as official and scientific tasters. The business owner was also involved as a taster from the restaurant practice.

Additionally, the seasonal quality of the pepper could reduce the overall quality of the dish. Nevertheless, the example of sensory analysis and statistical data evaluation is an added value for scientific work in gastronomy and the restaurant business, most probably for post-pandemic development in terms of quality, turnover, personnel, sustainable consumption, and food safety.

\subsection{Future Research}

For future research possibilities, we recommend extending the duration of the freezing period. Consequently, the quality problems could be accompanied by safety issues, possibly with microbiological testing (see Appendix A) [64,75]. Validation of the results for credible processes in a restaurant operation without further testing is essential. The research is estimated to obtain the whole standard (e.g., input, production steps (technological and thermal), the freezing period with a Celsius degree scale, and reheating procedures).

Nevertheless, information concerning allergens is essential to the restaurant business, whereas nutrition values are not. Therefore, the next step is to provide all vital nutrition values to restaurant customers. For an example of the calculated nutrition values of stuffed peppers, see Appendix $C$.

Further investigation based on the results made by the panel of three tasters or more regarding the quality of frozen food could add some new insight and contribute to the understanding of restaurant food processing.

\section{Patents}

The Slovenian Intellectual Property Office has recognised the invention result of nutrition values software for restaurant businesses as a patented trademark. The registration number is 201771159, and the E-filing is EFSI201700000014784. 
Author Contributions: Conceptualisation, S.G.; methodology, S.G.; software, S.G.; validation, S.G.; formal analysis, S.G.; investigation, S.G.; resources, S.G.; data curation, S.G.; writing-original draft preparation, S.G.; writing-review and editing, V.Š.; visualisation, S.G.; supervision, V.Š.; project administration, S.G.; funding acquisition, V.Š. All authors have read and agreed to the published version of the manuscript.

Funding: This research received no external funding.

Institutional Review Board Statement: The study was conducted according to the guidelines of the Declaration of Helsinki, and approved by Ethical Committee at the Faculty of Economics and Informatics, University of Novo Mesto, working within the Committee for Research (protocol code D-2-33/2021, date of approval: 30 September 2021).

Informed Consent Statement: Informed consent was obtained from all subjects involved in the study.

Data Availability Statement: Data are reported in Section 2: Materials and Methods.

Acknowledgments: We are grateful to Marlena Skvarča, who supervised the project and sensory analysis during her time at the University of Ljubljana. Special thanks are also given to the reviewers for their rigorous and comprehensive comments that contributed to the improvement of this article. The authors also thank George Neary for his professional editing. Finally, special thanks are offered to the restaurant owner, Metka Bilič.

Conflicts of Interest: The authors declare no conflict of interest.

\section{Appendix A}

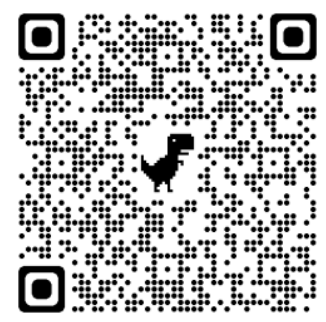

Figure A1. QR code to obtain the picture of a pepper used in sensory analysis.

Note. [76]. Reprinted with permission from ref. [76]. Copyright 2021, Copyright Nikola.

\section{Appendix B}

\begin{tabular}{|c|c|}
\hline $\begin{array}{l}\text { Escherichla } \\
\text { coll }\end{array}$ & $\begin{array}{l}\text { Aerobne } \\
\text { mezofine } \\
\text { bakterije }\end{array}$ \\
\hline S0 16649-2:2001 & \begin{tabular}{|l|} 
ISO \\
$4833: 2003$
\end{tabular} \\
\hline $\begin{array}{l}m=50 \\
y=5 \times 10^{2} \\
h=5 ; c=2\end{array}$ & $\begin{array}{l}n=5 ; c=2 \\
m=5 \times 10^{5} \\
M=5 \times 10^{6}\end{array}$ \\
\hline $\mathrm{CFU} / \mathrm{g}$ & CFU/g \\
\hline \multicolumn{2}{|c|}{ REZULTAT } \\
\hline 10 & 13000000 \\
\hline$k 10$ & $>30000000$ \\
\hline$k 10$ & $>30000000$ \\
\hline 10 & $>30000000$ \\
\hline 610 & $>300000000$ \\
\hline
\end{tabular}

Figure A2. Microbiological testing of raw minced meat.

Note. Aerobne, mezofilne, and bakterije = total aerobic mesophyll bacterium count; Rezultat $=$ results $[30]$. 


\section{Appendix C}

\begin{tabular}{|c|c|}
\hline per $100 \mathrm{~g}$ & $(\% *)$ \\
\hline energy value & $266 \mathrm{~kJ} / 3 \%$ \\
\hline fat & $2,4 \mathrm{~g} \quad 3 \%$ \\
\hline of which saturated & $5 \%$ \\
\hline carbohydrates & $6,9 \mathrm{~g} \quad 3 \%$ \\
\hline of which sugar & $1,8 \mathrm{~g} \quad 2 \%$ \\
\hline Protein & $3,4 \mathrm{~g} \quad 7 \%$ \\
\hline salt & $0,3 \mathrm{~g} \quad 5 \%$ \\
\hline * Recommend & for an \\
\hline
\end{tabular}

Figure A3. Nutrition values of stuffed yellow pepper (vegetables) with tomato sauce.

Note. Authors' calculations. Software patented TM $®[77-79]$. ${ }^{\text {TM }}$ Copyright 2017, Copyright Sergej Gričar. Reprinted with permission from ref. [77]. Copyright 2021, Copyright Gašper Repanšek.

\section{Appendix D}

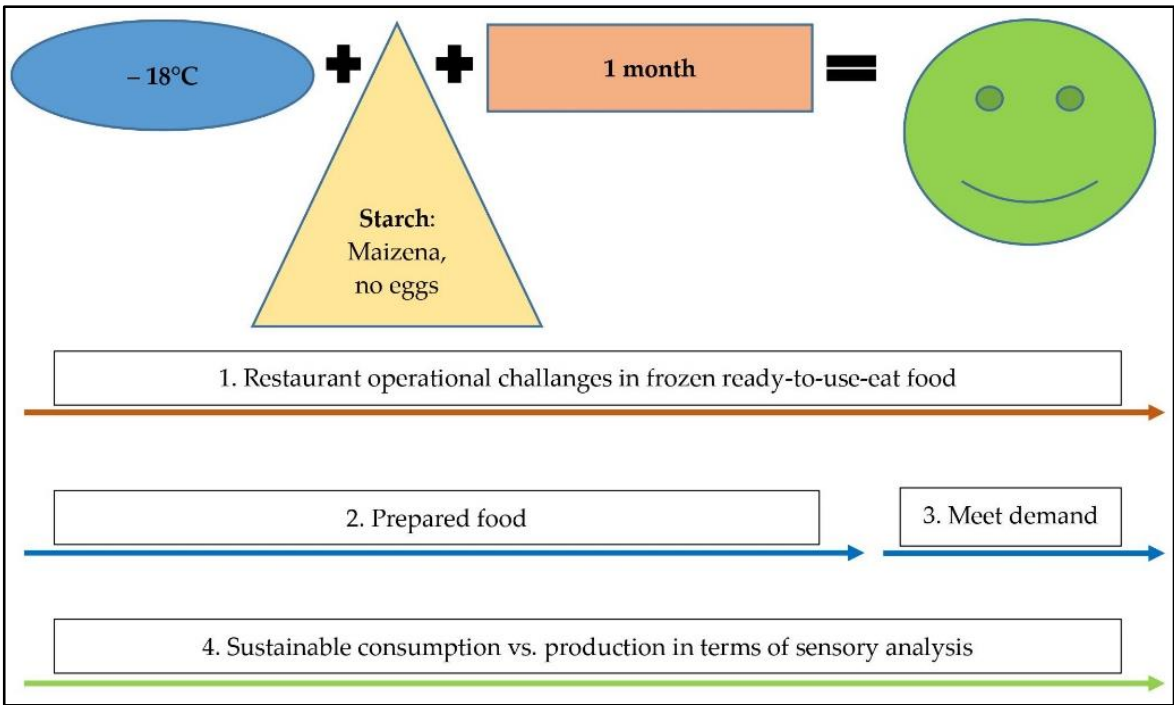

Figure A4. Optimised results indicated for processing of frozen stuffed peppers in the restaurant business [80].

Note. Authors' contribution. Copyright 2021, Copyright Sergej Gričar and Violeta Šugar.

\section{References}

1. Sen, S.; Antara, N.; Sen, S. Factors influencing consumers' to Take Ready-made Frozen Food. Curr. Psychol. 2021, 40, 2634-2643. [CrossRef]

2. Jeong, E.; Jang, S.S. Price Premiums for Organic Menus at Restaurants: What is an Acceptable Level? Int. J. Hosp. Manag. 2019, 77, 117-127. [CrossRef]

3. Google Scholar. Available online: https://scholar.google.si/scholar?hl=sl\&as_sdt=0\%2C5\&q=stuffed + pepper\&btnG= (accessed on 3 September 2021).

4. Del Chierico, F.; Vernocchi, P.; Dallapiccola, B.; Putignani, L. Mediterranean Diet and Health: Food Effects on Gut Microbiota and Disease Control. Int. J. Mol. Sci. 2014, 15, 11678-11699. [CrossRef] [PubMed]

5. Charmpi, C.; Van Reckem, E.; Sameli, N.; Van der Veken, D.; De Vuyst, L.; Leroy, F. The Use of Less Conventional Meats or Meat with High pH Can Lead to the Growth of Undesirable Microorganisms during Natural Meat Fermentation. Foods 2020, 9, 1386. [CrossRef] [PubMed] 
6. Aabo, S.; Andersen, J.K.; Olsen, J.E. Research Note: Detection of Salmonella in Minced Meat by the Polymerase Chain Reaction Method. Lett. Appl. Microbiol. 1995, 21, 180-182. [CrossRef]

7. Narasimha Rao, D.; Ramesh, B.S. Microbial Profiles of Minced Meat. Meat Sci. 1988, 23, 279-291. [CrossRef]

8. Haard N., F. Product Composition and the Quality of Frozen Foods. In Quality in Frozen Food; Erickson, M.C., Hung, Y.C., Eds.; Springer: Boston, MA, USA, 1997; pp. 275-295. [CrossRef]

9. Moon, K.M.; Kwon, E.-B.; Lee, B.; Kim, C.Y. Recent Trends in Controlling the Enzymatic Browning of Fruit and Vegetable Products. Molecules 2020, 25, 2754. [CrossRef]

10. Sikora, M.; Złotek, U.; Kordowska-Wiater, M.; Świeca, M. Spicy Herb Extracts as a Potential Improver of the Antioxidant Properties and Inhibitor of Enzymatic Browning and Endogenous Microbiota Growth in Stored Mung Bean Sprouts. Antioxidants 2021, 10, 425. [CrossRef]

11. Griffith, M.; Ewart, K.V. Antifreeze Proteins and their Potential use in Frozen Foods. Biotechnol. Adv. 1995, 13, 375-402. [CrossRef]

12. Pham, Q.T. Modelling Heat and Mass Transfer in Frozen Foods: A Review. Int. J. Refrig. 2006, 29, 876-888. [CrossRef]

13. Charoenrein, S. Microstructural Changes and their Relationship with Quality and Stability of Frozen Foods. In Woodhead Publishing Series in Food Science, Technology and Nutrition; Food Microstructure and Its Relationship with Quality and Stability; Devahastin, S., Ed.; Woodhead Publishing: Duxford, UK, 2018; pp. 123-138. [CrossRef]

14. Zhan, X.; Sun, D.-W.; Zhu, Z.; Wang, Q.-J. Improving the Quality and Safety of frozen muscle foods by Emerging Freezing Technologies: A Review. Crit. Rev. Food Sci. Nutr. 2018, 58, 2925-2938. [CrossRef]

15. Steinka, I.; Barone, C.; Parisi, S.; Micali, M. Technology and Chemical Features of Frozen Vegetables. In The Chemistry of Frozen Vegetables. Briefs in Molecular Science; Springer: Cham, Switzerland, 2017; pp. 23-29. [CrossRef]

16. van der Sman, R.G.M. Impact of Processing Factors on Quality of Frozen Vegetables and Fruits. Food Eng. Rev. 2020, 12, 399-420. [CrossRef]

17. Aguilera, J.M. Relating Food Engineering to Cooking and Gastronomy. Compr. Rev. Food Sci. Food Saf. 2018, 17, 1021-1039. [CrossRef]

18. Arthey, D. Freezing of Vegetables and Fruits; Springer: Zuerich, Switzerland, 1993; pp. 237-269.

19. Lucas, R. Industrial Relations in Hotels and Catering: Neglect and Paradox? Br. J. Ind. Relat. 1996, 34, 267-286. [CrossRef]

20. Namkung, Y.; Jang, S. Does Food Quality Really Matter in Restaurants? Its Impact On Customer Satisfaction and Behavioral Intentions. J. Hosp. Tour. Res. 2007, 31, 387-409. [CrossRef]

21. George, R.V.; Harsh, H.O.; Ray, P.; Babu, A.K. Food Quality Traceability Prototype for Restaurants Using Blockchain and Food Quality Data Index. J. Clean. Prod. 2019, 240, 118021. [CrossRef]

22. Ottenbacher, M.; Harrington, R.J. The Innovation Development Process of Michelin-starred Chefs. Int. J. Contemp. Hosp. Manag. 2007, 19, 444-460. [CrossRef]

23. Mun, S.G.; Jang, S.S. Restaurant Operating Expenses and their Effects on Profitability Enhancement. Int. J. Contemp. Hosp. Manag. 2018, 71, 68-76. [CrossRef]

24. Simpao, K.J.S. Labour Productivity Measurement and Control Standards for Hotel. J. Serv. Sci. Res. 2018, 10, 25-76. [CrossRef]

25. Baum, T. Does the Hospitality Industry Need or Deserve Talent? Int. J. Contemp. Hosp. Manag. 2019, 31, 3823-3837. [CrossRef]

26. Oruña-Concha, M.; González-Castro, M.; López-Hernández, J.; Simal-Lozano, J. Effects of Freezing on the Pigment Content in Green Beans and Padrón Peppers. Z. Lebensm. Unters. Forsch. 1997, 205, 148-152. [CrossRef]

27. Bernhardt, S.; Schlich, E. Impact of Different Cooking Methods on Food Quality: Retention of Lipophilic Vitamins in Fresh and Frozen Vegetables. J. Food Eng. 2006, 77, 327-333. [CrossRef]

28. Gričar, S. Influence of Freezing on the Sensory Quality of Stuffed Pepper. Bachelor Thesis, University of Ljubljana, Ljubljana, Slovenia, 22 November 1999.

29. Leistner, L.; Gorris, L.G.M. Food Preservation by Hurdle Technology. Trends Food Sci. Technol. 1995, 6, 41-46. [CrossRef]

30. Stražiščar, S.; Baler, D.; Gričar, S. HACCP System in Spar Slovenia; Spar Slovenia, d.o.o.: Ljubljana, Slovenia,, 2012.

31. Mercier, S.; Villeneuve, S.; Mondor, M.; Uysal, I. Time-Temperature Management Along the Food Cold Chain: A Review of Recent Developments. Compr. Rev. Food Sci. Food Saf. 2017, 16, 647-667. [CrossRef]

32. Symons, H. Frozen Foods. In Shelf Life Evaluation of Foods; Man, C.M.D., Jones, A.A., Eds.; Blackie Academic \& Professional: London, UK, 1994; pp. 296-316.

33. Mathlouthi, M. Food Packaging and Preservation; Springer: New York, NY, USA, 1994.

34. Man, C.M.D.; Jones A., A. Shelf Life Evaluation of Foods; Aspen Publishers: Gaithersburg, Maryland, 1994.

35. Marangoni Júnior, L.; Cristianini, M.; Anjos, C.A. Packaging Aspects for Processing and Quality of Foods Treated by Pulsed Light. J. Food Process. Preserv. 2020, 44, 14902. [CrossRef]

36. Aygörmez, Y.; Canpolat, O.; Al-mashhadani, M.M.; Uysal, M. Elevated Temperature, Freezing-Thawing and Wetting-Drying Effects on Polypropylene Fiber Reinforced Metakaolin Based Geopolymer Composites. Construction and Building Materials 2020, 235, 17502. [CrossRef]

37. Jordan, B.; Gorji, M.B.; Mohr, D. Neural Network Model Describing the Temperature- and Rate-Dependent Stress-Strain Response of Polypropylene. Int. J. Plast. 2020, 135, 102811. [CrossRef]

38. Czarnecka-Komorowska, D.; Nowak-Grzebyta, J.; Gawdzińska, K.; Mysiukiewicz, O.; Tomasik, M. Polyethylene/Polyamide Blends Made of Waste with Compatibilizer: Processing, Morphology, Rheological and Thermo-Mechanical Behavior. Polymers 2021, 13, 2385. [CrossRef] [PubMed] 
39. Eichner, K. Packaging and Storage of Cooled and Frozen Ready-to-serve Foods. In How Ready Are Ready-to-Serve Foods?, Proceedings of the International Symposium on Ready-to-Serve Foods, Karlsruhe, Federal Republic of Germany, August 1977; Paulus, K., Ed.; Karger: Basel, Switzerland, 1978; pp. 198-214. [CrossRef]

40. Nikmaram, N.; Budaraju, S.; Barba, F.J.; Lorenzo, J.M.; Cox, R.B.; Mallikarjunan, K.; Roohinejad, S. Application of Plant Extracts to Improve the Shelf-Life, Nutritional and Health-Related Properties of Ready-To-Eat Meat Products. Meat Sci. 2018, 145, 245-255. [CrossRef] [PubMed]

41. Lu, X.; Zhang, Y.; Xu, B.; Zhu, L.; Luo, X. Protein Degradation and Structure Changes of Beef Muscle during Superchilled Storage. Meat Sci. 2020, 168, 108180. [CrossRef] [PubMed]

42. Sarkar, T.; Salauddin, M.; Pati, S. The Fuzzy Cognitive Map-Based Shelf-life Modelling for Food Storage. Food Anal. Methods 2021. [CrossRef]

43. Suleman, R.; Wang, Z.; Muhammad Aadil, R.; Hui, T.; Hopkins, D.L.; Zhang, D. Effect of cooking on the Nutritive Quality, Sensory Properties and Safety of Lamb Meat: Current Challenges and Future Prospects. Meat Sci. 2020, 167, 108172. [CrossRef]

44. Roudaut, G. Water Activity and Physical Stability. In Water Activity in Foods; Barbosa-Cánovas, G.V., Fontana, A.J., Jr., Schmidt, S.J., Labuza, T.P., Eds.; John Wiley \& Sons, Inc.: Chicago, IL, USA, 2020. [CrossRef]

45. Kumar, P.K.; Rasco, B.A.; Tang, J.; Sablani, S.S. State/Phase Transitions, Ice Recrystallization, and Quality Changes in Frozen Foods Subjected to Temperature Fluctuations. Food Eng. Rev. 2020, 12, 421-451. [CrossRef]

46. Zhang, W.; Ma, J.; Sun, D.-W. Raman Spectroscopic Techniques for Detecting Structure and Quality of Frozen Foods: Principles And Applications. Crit. Rev. Food Sci. Nut. 2021, 61, 2623-2639. [CrossRef]

47. Qiu, L.; Zhang, M.; Chitrakar, B.; Bhandari, B. Application of Power Ultrasound in Freezing and Thawing Processes: Effect on Process Efficiency and Product Quality. Ultrason. Sonochem. 2020, 68, 105230. [CrossRef]

48. Boltman, B. Cook-Freeze Catering Systems; Applied Science Publishers: Beltsville, Maryland, USA, 1978.

49. Hultén, B. Branding by the Five Senses: A Sensory Branding Framework. J. Brand Strategy 2017, 6, $281-292$.

50. Wang, C.; Ghadimi, P.; Lim, M.K.; Tseng, M.-L. A Literature Review of Sustainable Consumption and Production: A Comparative Analysis in Developed and Developing Economies. J. Clean. Prod. 2019, 206, 741-754. [CrossRef]

51. Aschemann-Witzel, J.; Ares, G.; Thøgersen, J.; Monteleone, E. A sense of Sustainability? - How Sensory Consumer Science Can Contribute to Sustainable Development of the Food Sector. Trends Food Sci. Technol. 2019, 90, 180-186. [CrossRef]

52. Xu, S.; Chu, C.; Zhang, Y.; Ye, D.; Wang, Y.; Ju, M. Entangled Stakeholder Roles and Perceptions of Sustainable Consumption: An Evaluation of Sustainable Consumption Practices in Tianjin, China. J. Environ. Manag. 2018, 223, 841-848. [CrossRef]

53. Gricar, S.; Baldigara, T.; Šugar, V. Sustainable Determinants That Affect Tourist Arrival Forecasting. Sustainability 2021, $13,9659$. [CrossRef]

54. Martin-Woodhead, A. Limited, Considered and Sustainable Consumption: The (Non)consumption Practices of UK Minimalists. J. Consum. Cult. 2021. [CrossRef]

55. Guillen-Royo, M. Sustainable Consumption and Wellbeing: Does on-Line Shopping Matter. J. Clean. Prod. 2019, 229, 1112-1124 [CrossRef]

56. Dawkins, E.; André, K.; Axelsson, K.; Benoist, L.; Gerger Swartling, Å.; Persson, Å. Advancing Sustainable Consumption at the Local Government Level: A Literature Review. J. Clean. Prod. 2019, 231, 1450-1462. [CrossRef]

57. Piligrimienè, Ž.; Žukauskaitè, A.; Korzilius, H.; Banytè, J.; Dovalienè, A. Internal and External Determinants of Consumer Engagement in Sustainable Consumption. Sustainability 2020, 12, 1349. [CrossRef]

58. Fischer, D.; Reinermann, J.-L.; Mandujano, G.; DesRoches, C.T.; Diddi, S.; Vergragt, P.J. Sustainable Consumption Communication: A Review of an Emerging Field of Research. J. Clean. Prod. 2021, 300, 126880. [CrossRef]

59. Gričar, S.; Rodica, B. Academia-industry Nexus Management. Management 2016, 11, 309-326.

60. Lavriša, Ž.; Erjavec, K.; Pravst, I. Trends in Marketing Foods to Children in Slovenian Magazines: A Content Analysis. Public Health Nutr. 2018, 21, 3344-3353. [CrossRef] [PubMed]

61. Bolek, S. Consumer Knowledge, Attitudes, and Judgments About Food Safety: A Consumer Analysis. Trends Food Sci. Technol. 2020, 102, 242-248. [CrossRef]

62. Ruiz-Capillas, C.; Herrero, A.M.; Pintado, T.; Delgado-Pando, G. Sensory Analysis and Consumer Research in New Meat Products Development. Foods 2021, 10, 429. [CrossRef]

63. Hidas, K.I.; Visy, A.; Csonka, J.; Nyulas-Zeke, I.C.; Friedrich, L.; Pásztor-Huszár, K.; Alpár, B.; Hitka, G.; Felföldi, J.; Fehér, O.; et al. Development of a Novel Gluten-Free Egg Pie Product: Effects of Sensory Attributes and Storage. Sustainability 2020, $12,10389$. [CrossRef]

64. Machado Lopes, S.; César Tondo, E. Survival of Salmonella in Spaghetti Alla Carbonara. LWT 2020, 123, 109115. [CrossRef]

65. Álvarez, P.; Blanco, M.A. Reliability of The Sensory Analysis Data of a Panel of Tasters. J. Sci. Food Agric. 2000, 80, 409-418. [CrossRef]

66. Carvalho, P.G.; Santos, R.; Fino, A.; Ferreira, P.; M. Rodrigues, F.; Dias, J. Evolution during Three Ripening Stages of Évora Cheese. Foods 2020, 9, 1140. [CrossRef]

67. Vaclavik, V.A.; Pimentel, M.H.; Devine, M.M. Cereal and Starch. In Dimensions of Food; Springer, 1998. [CrossRef]

68. Conde-Petit, B.; Escher, F.; Nuessli, J. Structural Features Of Starch-Flavor Complexation in Food Model Systems. Trends Food Sci. Technol. 2006, 17, 227-235. [CrossRef] 
69. Heyman, B.; Depypere, F.; Delbaere, C.; Dewettinck, K. Effects of Non-starch Hydrocolloids on the Physicochemical Properties and Stability of a Commercial Béchamel Sauce. J. Food Eng. 2010, 99, 115-120. [CrossRef]

70. Stevanović, M. Phosphorylated Starch Derivatives in sterilised sauces. Bachelor Thesis, University of Ljubljana, Biotechnological Faculty, Ljubljana, 1989.

71. Light, N.; Walker, A. Food preservation: The Sensory and Nutritional Quality of Cook-chill Foods. In Cook- Chill Catering: Technology and Management; Light, N., Walker, X., Eds.; Elsevier Science Publisher Ltd: London, UK, 1990.

72. Duarte, A.M.; Silva, F.; Pinto, F.R.; Barroso, S.; Gil, M.M. Quality Assessment of Chilled and Frozen Fish-Mini Review. Foods 2020, 9, 1739. [CrossRef]

73. Sunanta, P.; Chung, H.-H.; Kunasakdakul, K.; Ruksiriwanich, W.; Jantrawut, P.; Hongsibsong, S.; Sommano, S.P. Genomic relationship and physiochemical properties among raw materials used for Thai black garlic processing. Food Sci. Nutr. 2020, 8 , 4534-4545. [CrossRef]

74. Kumar, S.; Baniwal, P.; Nayik, G.A.; Prasad, K.; Khan, K.A.; Ghramh, H.A.; Kumar, H.; Karabagias, I.K. Optimization and Development of Ready to Eat Chocolate Coated Roasted Flaked Rice as Instant Breakfast Food. Foods 2021, 10, 1658. [CrossRef]

75. Kasuga, F.; Hirota, M.; Wada, M.; Yunokawa, T.; Toyofuku, H.; Shibatsuji, M.; Michino, H.; Kuwasaki, T.; Yamamoto, S.; Kumagai, S. Archiving of Food Samples from Restaurants and Caterers-Quantitative Profiling of Outbreaks of Foodborne Salmonellosis in Japan. J. Food Prot. 2004, 67, 2024-2032. [CrossRef]

76. Old Varieties of Seeds. Available online: https://staresortesemena.com/wp-content/uploads/2018/08/Palana\%C4\%8Dkababaura-1.jpg (accessed on 27 September 2021).

77. Calculation of Nutrition Values. Available online: http:/ /ihv.si/ (accessed on 27 September 2021).

78. Gričar, S.; Rodica, B.; Bojnec, Š. Sandwich Management; University of Primorska Press: Koper, Slovenia, 2016 ; pp. 35-121.

79. Kaur, A.; Scarborough, P.; Hieke, S. The Nutritional Quality of Foods Carrying Health-Related Claims in Germany, The Netherlands, Spain, Slovenia and the United Kingdom. Eur. J. Clin. Nutr. 2016, 70, 1388-1395. [CrossRef]

80. Turner, E.R.; Luo, Y.; Buchanan, R.L. Microgreen Nutrition, Food Safety, and Shelf Life: A Review. J. Food Sci. 2020, 85, 870-882. [CrossRef] [PubMed] 